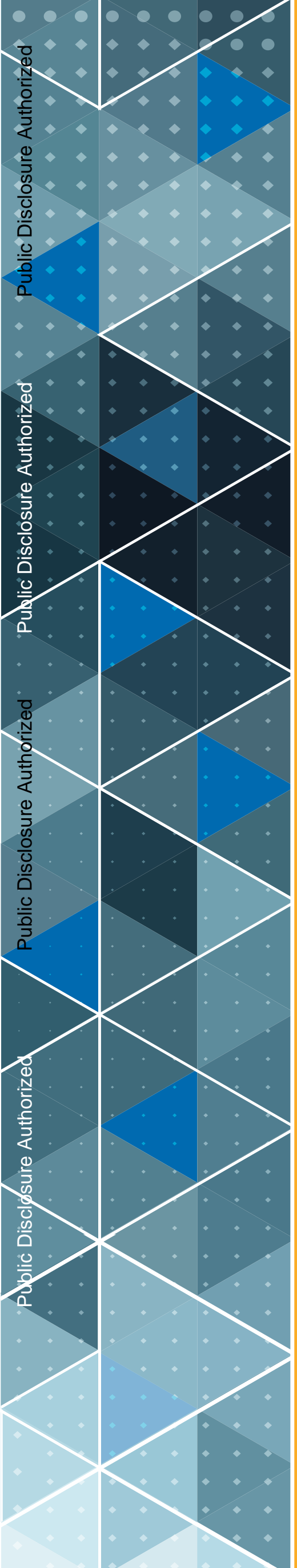

\title{
SOCIAL PROTECTION \& JOBS
}

\section{DISCUSSION PAPER}

No. $1914 \mid$ April 2019

\section{NDC Schemes and the Labor Market: Issues and Options}

Robert Holzmann, David Robalino, and Hernan Winkler 
(C) 2019 International Bank for Reconstruction and Development / The World Bank

\section{H Street NW}

Washington DC 20433

Telephone: +1 (202) 4731000

Internet: www.worldbank.org

This work is a product of the staff of The World Bank with external contributions. The findings, interpretations, and conclusions expressed in this work do not necessarily reflect the views of The World Bank, its Board of Executive Directors, or the governments they represent.

The World Bank does not guarantee the accuracy of the data included in this work. The boundaries, colors, denominations, and other information shown on any map in this work do not imply any judgment on the part of The World Bank concerning the legal status of any territory or the endorsement or acceptance of such boundaries.

\section{RIGHTS AND PERMISSIONS}

The material in this work is subject to copyright. Because The World Bank encourages dissemination of its knowledge, this work may be reproduced, in whole or in part, for noncommercial purposes as long as full attribution to this work is given.

Any queries on rights and licenses, including subsidiary rights, should be addressed to World Bank Publications, The World Bank Group, 1818 H Street NW, Washington, DC 20433, USA; fax: +1 (202) 522 2625; e-mail: pubrights@worldbank.org. 


\begin{abstract}
Defined contribution (DC) schemes - whether unfunded or funded - are often considered superior to defined benefit (DB) schemes in their ability to address labor market issues, particular in encouraging formal employment and delayed retirement. Conceptually, the assessment is based on superior incentives to work and save. Yet economic and social realities are more complex. This paper explores design and labor market conditions that potentially constrain DC schemes. The paper concludes that to achieve their conceptual potential, DC schemes require design innovations, including a better integration of basic provisions and complementary labor policies that promote job creation in the formal sector and expand job opportunities during old age.
\end{abstract}

Key words: Population Aging, Retirement Age, Labor Force Participation, Contribution Density, Elderly Labor Market

JEL codes: $\mathrm{H} 55, \mathrm{~J} 14, \mathrm{~J} 18$ 


\section{Acknowledgments}

This paper is written for Progress and Challenges of Nonfinancial Defined Contribution Pension Schemes, Volume 1: Addressing Marginalization, Polarization, and the Labor Market, edited by Robert Holzmann, Edward Palmer, Robert Palacios, and Stefano Sacchi, to be published by the World Bank in autumn 2019. We are grateful to Carmen Pages and Stefano Sacchi for pertinent comments and suggestions and to Amy Gautam for first-rate copy editing. A first version of the paper was presented at the NDC III conference in Rome, October 5-6, 2017, and we are thankful to the participants for their comments and encouragement. The views expressed herein are those of the authors and do not necessarily reflect the views of the institutions they are associated with or the views of the World Bank. 


\section{Abbreviations and Acronyms}

$\begin{array}{ll}\text { DB } & \text { Defined Benefit } \\ \text { DC } & \text { Defined Contribution } \\ \text { ECA } & \text { East Asia and Pacific } \\ \text { FDC } & \text { Europe and Central Asia } \\ \text { LAC } & \text { Latin America and the Caribbean } \\ \text { MILES } & \text { Macroeconomics, Investment, Labor Market, Education, and Skills } \\ \text { NDB } & \text { Nonfinancial Defined Benefit } \\ \text { NDC } & \text { Nonfinancial Defined Contribution } \\ \text { OECD } & \text { Organisation for Economic Co-operation and Development }\end{array}$




\section{Table of Contents}

1. Introduction: Background, issues, and structure ............................................. 6

2. Promises, shortcomings, and constraints of NDB and NDC schemes for formal labor

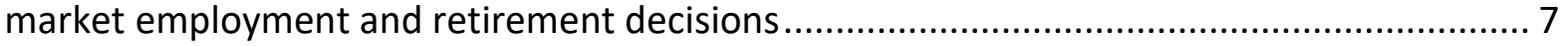

2.1. Constraints of NDB versus NDC schemes ...................................................... 8

2.2. Constraints beyond mandated schemes' design ............................................. 12

2.3. The need for complementary labor market interventions................................... 14

3. NDC schemes and formal labor force participation/employment ............................. 16

3.1. Key NDC design suggestions and other policies to improve labor market outcomes. 16

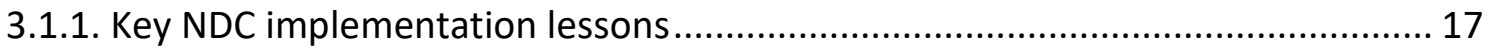

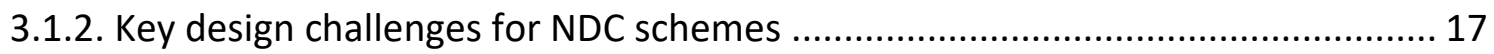

3.1.3. Main labor market policy challenges and options........................................ 19

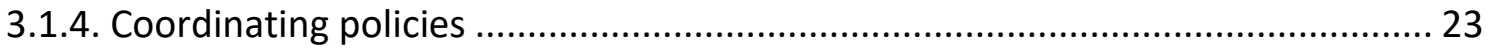

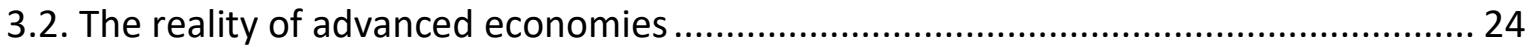

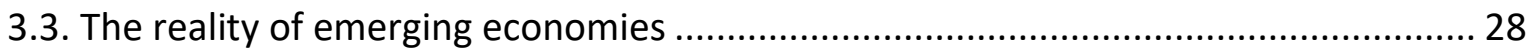

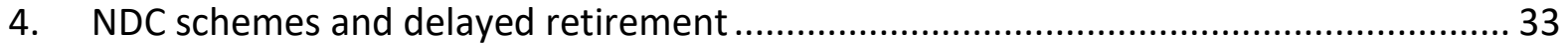

4.1. Key NDC design suggestions and main labor market policy actions/options ............. 34

4.1.1. Key NDC design issues for retirement delay ................................................ 34

4.1.2. Key labor market policy challenges and options ......................................... 37

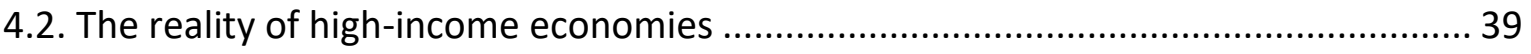

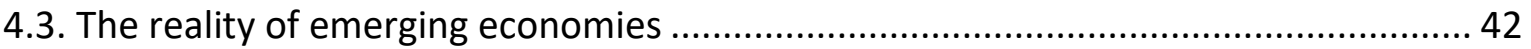

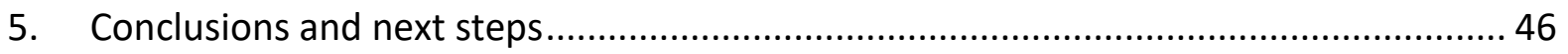

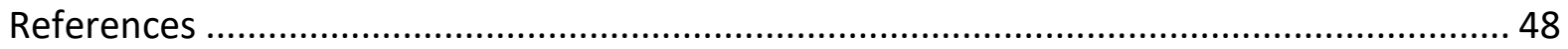




\section{Introduction: Background, issues, and structure}

Defined contribution (DC) schemes - whether unfunded or funded - are typically considered superior to defined benefit (DB) schemes in their ability to address many issues, including their capacity to encourage formal labor force participation and employment (and therefore increase the density of contributions), and later retirement in an aging population. A higher rate of formal labor force participation is expected through the one-toone contribution-benefit link, which reduces the tax wedge: Individuals get back what they paid in, with a sustainable rate of return; not less but also not more. In addition, in a world of continuously rising life expectancy, a DC benefit based on remaining life expectancy is expected to encourage later retirement, as individuals receive a lower benefit for a fixed retirement age (i.e., the actual or notional account values at retirement are essentially divided by the expected remaining life expectancy at any selected retirement age). Yet economic and social reality is more complex, and design and implementation issues may preclude DC schemes in general, and nonfinancial defined contribution (NDC) schemes in particular, from living up to their promise. Initial and enabling labor market conditions also matter and may be different for emerging (middle-income) and advanced (high-income) economies. For many low-income economies, the enabling conditions for an NDC scheme may simply not exist and are difficult to establish.

An important issue is provision of a minimum income support for the elderly. A budgetfinanced minimum income guarantee to all elderly (a social pension) is considered a necessary complement of any DC scheme for social, economic, and political reasons. Yet such a provision breaks the close contribution-benefit link of an NDC scheme, provides incentives to reduce labor supply, and encourages informality and early retirement. Another

element to take into consideration is the lack of proper skills among the elderly to allow them to delay retirement and continue working. Other structural issues can also compromise the performance of NDC schemes - for instance, the heterogeneity in longevity that makes the scheme less interesting for lower-income individuals, who have shorter life 
expectancies; behavioral biases that affect retirement and savings decisions; and institutional capacity to manage DC schemes.

This paper identifies key design features of NDC schemes that can affect formal labor market participation, contribution densities, and incentives for delayed retirement; including the architecture to guarantee a minimum income to the elderly. The paper also discusses the types of integrated labor policies and programs that countries need to consider to enable the proper functioning of an NDC scheme and how these likely vary between emerging and advanced economies. The paper offers a framework for policy analysis and selective recommendations but does not offer a fully developed and comprehensive set of policy proposals.

Section 2 opens with a conceptual framework that contrasts the labor market distortions induced by typical nonfinancial defined benefit (NDB) schemes with the labor market promises of NDC schemes; it then highlights the constraints that can affect the latter's performance. This provides the conceptual background and benchmark for the discussion about NDC design features that can promote formal participation/employment (section 3), and for the labor market policy discussion to allow the elderly to work longer (section 4). Both of these sections 3 and 4 first present key NDC design features and labor market policy proposals, and then highlight differences in realities in advanced and emerging economies. Section 5 summarizes the implications for NDC design and labor market policy actions and suggests next steps.

\section{Promises, shortcomings, and constraints of NDB and NDC schemes for formal labor market employment and retirement decisions}

Two preconditions must be met to ensure broad coverage, adequate pensions, and financial sustainability in mandatory pension schemes: (i) high formal labor force participation and employment; and (ii) long working careers. Other key objectives of a pension system may be achieving equity and risk sharing within and between generations. Alternative pension schemes can affect the labor market in different ways and are affected differently by labor 
market dynamics. (N)DB schemes are considered to be less supportive of higher labor force participation, formal employment, and adequate retirement decisions than (N)DC schemes. ${ }^{1}$ At the same time, the performance of both mandatory DB and DC schemes is affected by the structure of labor markets. When farm work and own-account work are more prevalent than wage employment, or when firms have few incentives to invest and create jobs and workers few incentives to take them, the performance of mandatory systems can be compromised. Hence, the design of the pension scheme is not enough. Policy makers also need to address constraints that affect the structure and performance of the labor market.

This section starts out by highlighting the conjectured advantages of NDC schemes compared to documented pitfalls of traditional as well as reformed NDB schemes to deliver high formal labor force participation and delayed retirement. It next outlines behavioral and other constraints that may impede the achievement of labor market objectives even under a well-done NDC scheme; this calls for new policy interventions. The section ends by sketching key labor market limitations that need to be overcome for NDC schemes to deliver on their labor market promises.

\subsection{Constraints of NDB versus NDC schemes}

The promises of an NDC scheme regarding labor market participation are best seen in comparison to the widely reported drawbacks of traditional NDB schemes. While in recent years many NDB schemes underwent reform, mostly in the direction of NDC schemes' operations, none of these NDB reforms were able to fully replicate the characteristics of an NDC scheme. ${ }^{2}$

\footnotetext{
${ }^{1}$ The discussion on whether NDC or financial defined contribution (FDC) schemes provide better labor market responses is not yet closed. Conceptually, FDC schemes with a higher financial rate of return should dominate NDC schemes with a lower notional rate of return. Empirically, however, is it unclear if this is the case. Emerging economies typically see a much higher wage growth than the rate of return of decentralized or centralized pension funds, except perhaps in the past in Chile.

${ }^{2}$ For a primer on NDC schemes, and a stylized comparison between NDB and NDC schemes, see Holzmann (2017b, 2019).
} 
NDB schemes are said to reduce formal employment and distort retirement decisions for a number of design reasons, particularly because:

- The absence of a close link between contributions and benefits creates a tax/subsidy wedge that risks distorting labor demand and supply decisions. This tax wedge is typically implicit, changes over an individual's lifecycle and between groups, and is strengthened through explicit and implicit redistributive interventions. More generally, the interaction of DB schemes with noncontributory arrangements may create implicit taxes/subsidies on formal and informal jobs that depend on the earnings profile of workers (Pages, Rigolini, and Robalino 2014).

- The mandated contribution rate is too high in many countries for the savings preferences of a significant part of the population, making participation less attractive for both low- and high-income earners. ${ }^{3}$

- The lack of sufficient adjustments for earlier (later) retirement creates incentives for retirement at the earliest possible age. It contributes to a "tax force that keeps labor force participation of elderly low" (Gruber and Wise 1998). Gruber and Wise's graph, enriched by the comparable data point for Austria, offers a powerful message on the importance of actuarial design for labor force participation around the retirement age (Figure 2.1).

\footnotetext{
${ }^{3}$ This point may also apply to not-well-designed and implemented NDC schemes in which the contribution rate pays for the legacy costs from the old NDB scheme, or if the mandate to save is simply too high.
} 
Figure 2.1: The link between unused labor capacity and the "tax force to retire"

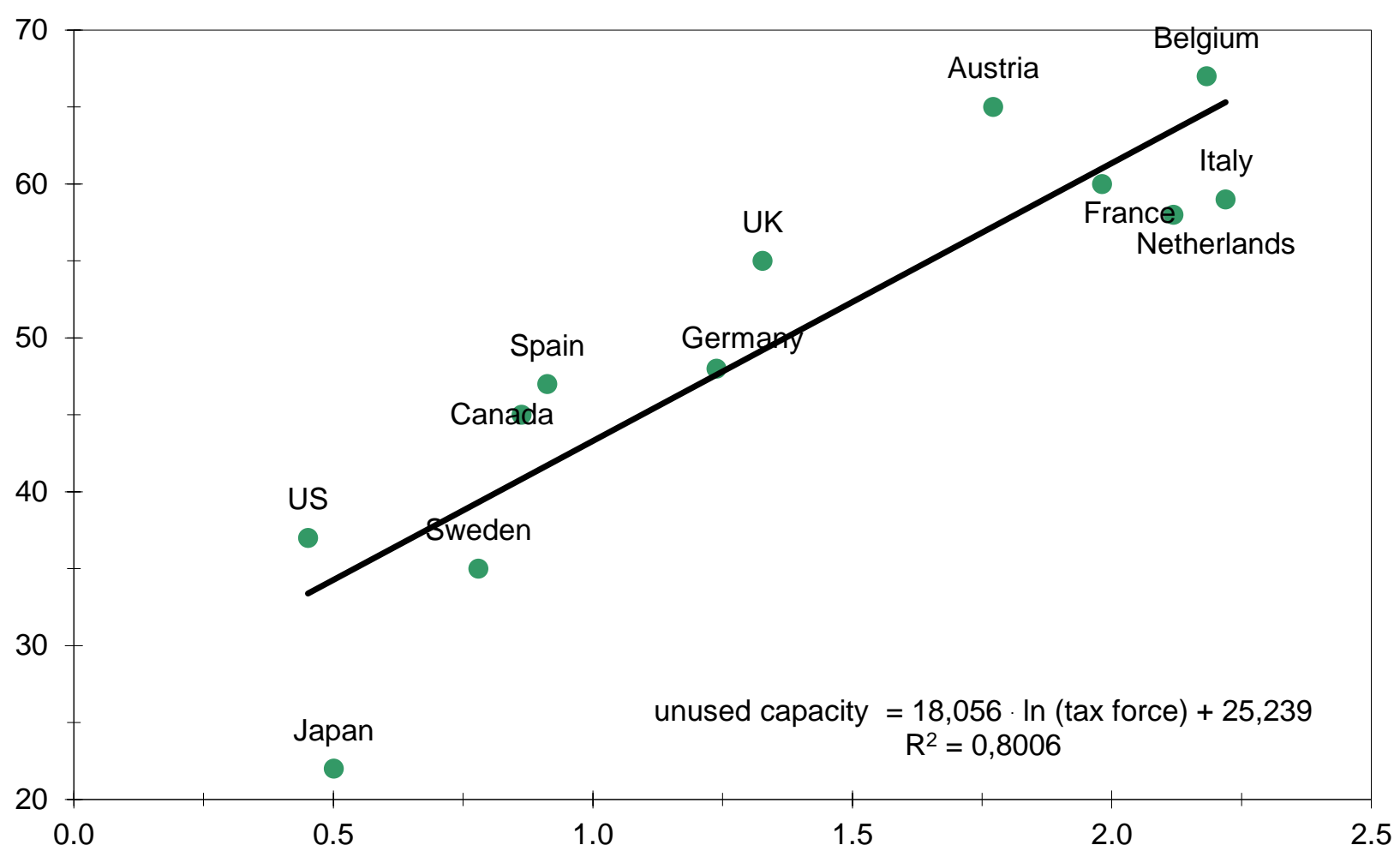

Source: Authors, based on Gruber and Wise 1998; Hofer and Koman 2006.

Note: "Tax force to retire" is the sum of the implied tax rates on continued work beginning at the earliest retirement age running through age 69 , which is a measure of the tax incentive for early retirement.

- Increasing the standard retirement age (i.e., where full benefits are received) in line with rising life expectancy requires repeated politically difficult decisions. Even if indexed with some measure of change in life expectancy, the approach typically remains imperfect as the wrong remaining life expectancy is applied (period instead of cohort), the decision is often delayed, and concomitant changes such as a reduction in the annual accrual rates are not undertaken.

- NDB schemes are less supportive of labor mobility across sectors and between countries. Their redistributive character often leads to very long waiting periods that increase the tax character of the contributions, and bilateral social security agreements (BSSAs) are required to establish totalization. 
In contrast, the move toward an NDC scheme promises a number of features that reduce distortions on formal labor market participation/employment and retirement decisions, in particular:

- The strongest possible contribution-benefit link, which reduces most or all of the implicit taxes/subsidies (except one that may emerge through the difference between a risk-adjusted higher financial market interest rate and the internal rate of return); this should foster labor market participation and formal employment.

- A linear intertemporal budget constraint for individuals that makes the retirement decision smooth and dependent only on individual preferences and own resources (i.e., NDC eliminates the kinks with clustering of retirement decisions around specific age or contribution levels); this should make way for an automatic increase in the effective retirement as life expectancy increases, as individuals receive a lower initial benefit if they retire under the previously envisaged retirement age.

- A lower, mandatory contribution rate, often envisaged under an NDC reform of a former NDB scheme. This should facilitate higher formal labor force participation and later retirement (assuming a less distortionary way than contributions to finance the legacy costs can be found; Holzmann and Jouston 2013).

- Easier labor mobility, as notional accumulations can be easily carried across jobs and geographic locations and are not subject to complex and tedious BSSAs (Holzmann and Koettle 2015; Holzmann 2017a).

Clearly, the NDC system needs to recognize that: (i) many low-wage workers may not be able to accumulate enough contributions to finance an adequate pension during retirement; and (ii) because of transitions between inactivity, unemployment, and formal and informal employment, not all workers are able to have full careers. This calls for minimum pension guarantees and/or matching contributions to promote retirement accumulations. Both can distort labor markets although, presumably, in more controlled and predictable ways than in the case of DB systems. For example: 
- Subsidies can take the form of universal or means-tested benefits or frontloaded provisions through matching contributions. Depending on their design, they will generate income and substitution effects that affect labor supply and retirement decisions. For instance, universal pensions have an income effect and strong empirical evidence shows that they can induce early retirement (Bertrand, Mullainathan, and Miller 2003). As they do not have a substitution effect, they do not distort the decision to move from a low-paying to a high-paying job, or from a formal to an informal job. Means-tested social pensions will have an additional substitution effect and distort choices between formal and informal jobs; for instance if eligibility only applies to those who do not participate in contributory systems or those with a level of income or pension below a certain threshold (i.e., there is 100 percent marginal tax rate on the subsidy after a given level of income). To address the incomplete participation of marginal workers on the labor market, NDC schemes are induced to offer encouragements for formal labor force participation through temporary matching contributions, lump-sum contribution transfers (e.g., for migrant workers), etc. ${ }^{4}$ While they may be designed to improve participation and contribution density, they may affect formal early retirement decisions either through their design or merely their income effect.

- As in FDC schemes, the initial pension benefit is determined essentially by the accumulation at retirement and life expectancy at this age. Low-income individuals (who exhibit markedly lower life expectancy in all countries) can easily see that the approach is a bad deal for them; thus, they avoid formal labor force participation and resist an increase in the retirement age.

\subsection{Constraints beyond mandated schemes' design}

Even the best designed mandated NDC schemes are confronted with constraints and distortions outside their making but likely heavily influenced by them. The most common

\footnotetext{
${ }^{4}$ See Palacios (2019) for a discussion of a universal NDC scheme.
} 
problem is that the mandate to participate in the scheme can, depending on workers' preferences and unconstrained behaviors, become an implicit tax that the NDC approach aims to minimize. Recent policy research stresses the effects of lacking or incomplete information and behavioral biases that may preclude scheme participation from happening or render retirement decisions not based on design incentives as envisaged. The main considerations are as follows:

- The many other risks individuals are exposed to and the incompleteness of financial markets in emerging and even advanced economies make contributions to an NDC scheme little attractive. The more relevant these other risks are and the more incomplete the financial markets, the less attractive is any future annuity promise by any mandated or even voluntary scheme (Davidoff, Brown, and Diamond 2005; Holzmann and Hinz 2005).

- The existence of other risk management instruments (such as family as a risk pool and general poverty-oriented public provisions) reduces the incentives for paying for a public annuity even if it is fully credible and actuarially fair (Kotlikoff and Spivak 1981).

- The total costs of formality (such as licenses, taxes, the social insurance bundle, etc.) increase the costs of contributing, even to a perfect DC scheme for both employers and employees, and encourage informality (Almeida and Carneiro 2012).

- The credibility of government and social security institutions is often low (this could also apply to a newly introduced/reformed NDC scheme, with consequences for formality and contribution efforts; Arias et al. 2007).

- Even in advanced economies, individuals complain about the lack of information about the working of NDC/NDB schemes, their economic basics, and the level of financial literacy. How best to offer the information about DC design and financial status of individual accounts is still unknown, while the role of financial literacy and the effectiveness of financial education remain under-researched (Holzmann 2014). 
- Behavioral limitations (such as hyperbolic discounting, loss aversion, and behavioral biases) may also apply to NDC schemes (Frölich et al. 2014). In turn, their proposed instruments to overcome these limitations will have to be added to the NDC design. This may include the nudging effect of a life expectancy-indexed standard retirement age under an NDC approach as a signaling device, albeit only a formally indexed minimum access age is likely needed, while the rest can be left to individual decision. The same applies to the need for an improved decision environment for contribution payments for part-time employees and the self-employed (Delarue 2013.

\subsection{The need for complementary labor market interventions}

Even perfectly designed NDC schemes and policies that are able to address the key constraints highlighted above will not be sufficient to generate the desired labor market effects of high formal labor force participation/employment and delayed retirement. Other types of government interventions are required to address some of the following problems facing emerging and high-income countries:

- Technological advances are changing the demand for different types of skills (from manual/repetitive to analytical/interpersonal) and changing the world of labor. Even if the introduction of new technologies such as robots and artificial intelligence brings opportunities to create new products and therefore new types of jobs, disruptions in the labor market will still affect certain workers' capacity to participate in NDC schemes. New technologies are also increasing the prevalence of self-employment and reducing the share of wage employment (Gentilini et al. forthcoming).

- Related to the above, more rapid technological change may result in skills becoming obsolete at a faster rate, a phenomenon that will be exacerbated in rapidly aging countries. The existence of market failures in the provision of lifelong learning by firms and educational institutions implies that the level of human capital acquisition 
throughout the lifecycle is suboptimal. Furthermore, some strands of education such as apprenticeship programs favor early labor market integration and higher wages, an advantage that is getting lost at higher ages to those with a more general education (Hampf and Woessmann 2017).

- The continued existence of mobility barriers across jobs, occupations, and geographic locations contributes to labor market disruptions, and thereby impedes the ability of workers to contribute constantly to pension savings.

- Many countries are still struggling to accelerate the rate of employment creation in the formal sector, which depends on firm dynamics (creation, growth, and destruction). Evidence indicates that most jobs are created by new firms, but insufficient firm entry is observed across middle-income countries. At the same time, few firms survive beyond five years and those that do may not grow. While countries are generally expanding employment in line with their labor force growth, many of these jobs are in low-productivity, informal activities (Merotto, Weber, and Aterido 2017).

- Many or all high-income countries are struggling with the increasing marginalization of part of the labor force due to less secure entry points when young (short-term contracts, low or no pay, and little or no on-the-job-training); part-time work; numerous unemployment spells when middle-aged; and downgraded job offers or unemployment when older. For most or all emerging economies, stubborn informality is the rule rather than the exception for many reasons, including inadequate social and labor market policies.

- In many emerging economies, large gender gaps in labor force participation and wages create additional challenges. When women face barriers to labor force participation and employment (driven by, for instance, a lack of child care services and maternity leave benefits, social norms, or regulations), countries need to implement gender-specific policies to improve women's labor market outcomes. 
- The existence of lagging regions in poor countries implies that even when the macroeconomic context and the overall business environment are conducive to job creation, it may only benefit those individuals in the leading urban areas.

- Institutional failures can generate health and education systems that are not able to keep the elderly healthy, skilled, and motivated to stay in the labor market. Employers may also fail to offer quality jobs to the elderly. To be healthy, skilled, and motivated is claimed as a necessary condition to extend labor force participation in old age in line with increasing life expectancy (Holzmann 2013).

The following two sections focus on this set of policy challenges for advanced and emerging economies: first on scheme design issues, then on labor market issues.

\section{NDC schemes and formal labor force participation/employment}

The previous sections identified formal labor force participation/employment with high contribution densities as one crucial element for a successful NDC scheme. Section 3.1 discusses the types of NDC design issues that need to be (re-)considered to achieve these outcomes, as well as the role of macro/regulatory, labor, and sectoral/regional policies. The next two subsections highlight broad trends in demographic, labor market, and pension scheme outcomes and identify labor market policy issues that need to be addressed in advanced (section 3.2) and emerging economies (section 3.3).

\subsection{Key NDC design suggestions and other policies to improve labor market outcomes}

NDC schemes are relatively simple in design, yet to deliver on their promises the transition from an NDB system needs to follow certain rules (Holzmann and Palmer 2012; Holzmann 2017b, 2019). Section 3.1 first presents the relevant lessons drawn from the limited number of NDC countries with broadly successful and less successful experience before moving to the labor market side. 


\subsubsection{Key NDC implementation lessons ${ }^{5}$}

- Do not pick and choose some NDC design features while otherwise staying within the inherited NDB scheme. Doing so will not create the expected labor market incentives or the expected pension benefit advantages. Hybrid schemes have not proven successful.

- Ensure that the demanding administrative requirements are in place before launching the individual account system, including individual identifiers, an ICT and payment system, and methods to establish and apply cohort life expectancies at relevant retirement ages (Palacios 2019).

- Establish the NDC logic as quickly as possible (i.e., avoiding lengthy transitions with parallel NDC/NDB schemes; no contribution financing of any legacy costs; uncertainty about the balancing mechanism in case of economic or demographic shocks; etc.). Any of these deviations or even delayed introduction after mishaps risks diluting the expected labor market incentives and credibility of the scheme.

\subsubsection{Key design challenges for NDC schemes}

NDC schemes need to be able to address four key issues: (i) how to minimize implicit taxes resulting from heterogeneous life expectancies that can reduce participation among lowincome/low-skilled workers; (ii) how to ensure a minimum level of income for workers who might not be able to contribute enough; (iii) how to extend coverage to the informal sector, particularly farmers and self-employed workers; and how (iv) how to design sustainable survivors' and disability pensions without discouraging participation. Possible innovations to address these issues include:

- Heterogeneous life expectancy. The increasing availability of data on heterogeneity in longevity suggests a strong and positive link between lifetime income position and life expectancy that seems to increase over time (Ayuso, Bravo, and Holzmann 2017a). Such heterogeneity is equivalent to a tax/subsidy mechanism when applying

\footnotetext{
${ }^{5}$ This prescriptive-sounding summary builds on the papers in NDC I, II, and III publications. For the refined and extended 10 key messages and lessons, see Holzmann (2017b, 2019).
} 
an average cohort life expectancy for the calculation of the pension benefit at retirement: low-income groups pay a tax that can reach 30 percent and more, while high-income groups receive a subsidy of similar magnitude (Ayuso, Bravo, and Holzmann 2017b). To correct for such distortions a number of options are available. One promising option is a two-tier contribution approach that allocates under an overall total contribution rate one share of contribution payments to the individual account according to the average and the remainder according to individual income. Hypothetical NDC calculations using US and UK social security data suggest that onefifth or less of the social contribution rate as part of the total contribution rate would be sufficient to address most of the longevity heterogeneity effects (Holzmann et al. 2017, 2019).

- Low-income workers and incomplete careers. The proper integration of minimum pension guarantees and anti-poverty programs (zero pillar) with the NDC scheme to minimize labor market distortions is a key challenge. The best options are still unclear and limited country experience exists regarding how well the current zero provisions are working (Finezylber 2019; Nelson, Nieuwenhuis, and Alm 2019; Palacios 2019). Some general principles can be considered, however: (i) transfers should be explicit and financed through a reallocation of general revenues or increased nonpayroll taxes; (ii) transfers should be universal or allocated based on means (not where people work); and (iii) when targeted on the basis of means, clawback rates should decrease gradually, generating low marginal tax rates (Ribe, Robalino, and Walker 2012).

- Self-employed and small-scale employers. Worldwide experience with small-scale employers, farmers, infrequent workers, and the self-employed suggests that these groups cannot be easily integrated into a pension scheme even if it is actuarially fair (e.g., an FDC or NDC scheme). For the self-employed this may be due to different cash flow needs while active and investing, but also when inactive and running down own assets. In addition, the income of these groups can be subject to frequent 
fluctuations, which makes it difficult to commit to a period, fixed payment based on a fictional income. Changing the contribution payment taking into consideration these fluctuations can improve incentives to contribute. This was shown, for instance, in experiments with fishermen in Africa that allowed for infrequent payments (at the time when the catch is sold) through the purchase of contribution vouchers (Delarue 2013). Again, general principles that can be followed when considering innovations are that: (i) it is important to separate the problem of ID/registering/enrolling workers from the problem of providing incentives to contribute; (ii) new ICTs massively reduce the cost of identifying and enrolling workers; (iii) new ICTs facilitate/reduce the cost of financial transactions and facilitate the collection of contributions; and (iv) financial and nonfinancial incentives can motivate people to save, according to some evidence (Akbaş et al. 2016).

- Survivors' and disability pensions. The design of survivors' and disability benefits under the typical NDB scheme has typically proven to be not conducive to enhanced labor force participation and delayed retirement. Carrying these benefit programs over to an NDC approach without reform risks continued or even worsened labor market distortions. This calls for their reform in particular, as reform innovations exist for both survivors' and disability benefits that promise to render them much more labor market-neutral. Kruse and Ståhlberg (2017) explore these two benefits' reform options in addition to long-term care programs.

\subsubsection{Main labor market policy challenges and options}

The goal of productive formal employment for the active population is a challenge for all countries in the world. The traditional approach is to treat jobs as a byproduct of economic growth. Countries simply need to promote investment and improve allocative efficiency by fixing market and government failures in product, capital, and labor markets. Indeed, in general, when economies grow they create jobs. And when no distortions exist in the allocation of resources - labor and capital - those jobs are created in the sectors and 
economic activities where they generate the most value. Thus, over time, jobs tend to move from low- to higher-productivity sectors, from rural to urban areas, and from informal to formal activities. These "structural transformations" then contribute to lift people out of poverty and increase standards of living. To achieve this, countries must have in place the right macroeconomic policies to ensure stability and reduce uncertainty; a business environment (including appropriate infrastructure) that reduces transactions costs and promotes competition and entrepreneurship; governance and the rule of law to enforce contracts and the possibility to appropriate returns on investments; education and health policies to have healthy workers with the right skills; and labor policies to reduce friction in the labor market, improve matching, and protect workers from abuse and exploitation (MILES framework ${ }^{6}$; Banerji et al. 2008). Because the agenda is complex, proposals have been made to identify the "most binding constraints" to investments and economic growth (Haussmann, Rodrik, and Velasco 2005).

In practice things are difficult. Identifying binding constraints remains an art more than a science. Governments usually push several policy agendas at the same time, and which reforms go through depends more on political opportunities (the political economy of reforms) than rigorous economic analyses (Tommasi and Velasco 2007). The reality is that even in countries such as Chile, Georgia, Mexico, or Uganda, which excelled in adopting key structural reforms and promoting investments and growth, the performance of labor markets did not necessarily improve. Yet without guidance on what is believed to prevent employment creation with productivity growth, the result is often a laundry list of analyses and proposals that are difficult to agree on, implement, and assess. One approach is to hypothesize the specific key binding constraints for a country based on preliminary analyses and good economic intuition and substantiate them with detailed empirical analyses

\footnotetext{
${ }^{6}$ MILES stands for Macroeconomics, Investment, Labor Market, Education and Skills, and Social Protection and thus the five key areas that may harbor the constraints for productive employment. Hence low labor force participation and high unemployment may emerge from any of these demand and supply areas, which should be identified and addressed.
} 
thereafter (see Bodor and Holzmann [2016] for Saudi Arabia). Another approach is to have a general hypothesis and develop policies accordingly.

The latter approach characterizes the hypothesized presence of job externalities that create a gap between social and private rates of return on investments (World Bank 2012). One externality (labor externality) emerges in the presence of high inactivity/unemployment and underemployment, when the market price of labor deviates from its social opportunity cost. The other externality (social externality) appears when jobs generate value beyond that appropriated by the employer and the workers. For instance, youth who work learn on the job, build their human capital, and make other workers in the economy more productive; women who have a job have fewer children and invest more in their human capital; and jobs for certain population groups can contribute to social stability (Robalino and Walker 2017). These externalities imply that private investments that are efficient from a social point of view may not take place. The World Bank has proposed a new policy direction that offers a sophisticated set of interrelated policy actions under the new jobs strategy approach (Box 3.1). 


\section{Box 3.1: New policy directions in the labor market}

Jobs strategies versus growth strategies. Countries should start to rely more on jobs strategies (different from growth strategies) with specific objectives in terms of: (i) accelerating the rate of job creation in the informal sector of the economy; (ii) improving the quality and earnings associated with informal jobs; and (iii) helping workers move from unemployment/inactivity into a job or from low- to higher-productivity jobs. Macro and regulatory policies, labor policies, and sectoral/regional policies can then be mapped to these outcomes and inform priorities in terms of reform, taking jobs externalities into account.

Macro and regulatory policies. Beyond having the right business environment and governance arrangements, ensuring investments in infrastructure, and reforming education and technical and vocational education (TVET) systems, two challenges arise from a jobs perspective: (i) how to prioritize reforms (e.g., which are the binding constraints if the focus is job creation in the formal sector); and (ii) how to balance the economic costs and benefits of economic transformations taking into account social externalities related to jobs. For example, the optimal path of fiscal adjustment in highly indebted countries might be more gradual when job losses are factored in. A similar gradual approach might be needed when implementing policies to promote trade liberalization, eliminate restrictions on capital flows, or change the relative prices of tradable versus nontradable goods.

Labor policies. Labor regulations and active labor market policies (ALMPs) have an important role in dealing with labor market failures and jobs externalities. To that end, however, it is necessary to rethink their design. Labor regulations need to be more efficient at protecting workers, including in the informal sector, while internalizing the social costs of jobs destruction and reducing distortions that constrain the creation of formal jobs. This implies: allowing firms to manage human resources as long as there is proper advance notice for dismissal; considering different approaches to guarantee a minimum level of income and ensure a fair distribution of value added between wages and profits; strengthening unemployment benefit systems while reducing the agency of employers; and enforcing core labor standards and adequate working conditions by relying more on civil society and less on labor inspectors. 


\subsubsection{Coordinating policies}

Whatever the approach, coordination across government entities is critical. While government heads like to call the Minister of Labor when the labor market underperforms, this minister may actually have the least influence on labor market outcomes. As suggested by both the MILES framework and the World Bank jobs strategy, it is critical to coordinate policies because:

- The experience in country after country suggests that the labor market-relevant ministers in a government hardly ever talk to each other about how best to achieve employment outcomes. When they are united in a panel discussion on labor market performance convened by international organizations, it may be the first time they talk to each other on the topic (Banerji et al. 2008). This reflects the widespread lack of any or clear coordinating mechanisms and institutions among the key policy players.

- The experience for emerging economies at least suggests that the Minister of Social Affairs (in charge of pension reform), the Minister of Labor (in charge of labor market reforms), and the Minister of Finance and/or Economy/head of central bank (in charge, or part of the financial sector reform) generally have high but largely unspecific expectations about what each can bring to the table and they hardly ever talk to one another about expectations and possible deliverables (Holzmann, Mackellar, and Repansek 2009).

- The lack of policy interaction within the government is reflected in the scarcity of rigorous impact evaluations of policy interventions across much of the world. Few labor market interventions and even fewer pension reform interventions have any kind of rigorous monitoring and evaluation that could be used to improve their performance over time. The impression is that emerging economies with World Bank and other multilateral institutions' support may have - in general - a higher level of rigorous monitoring and evaluation than do advanced economies. 
- Nonetheless, some recent examples exist of countries that have been able to coordinate the preparation of multisectoral jobs strategies and/or the implementation of integrated jobs operations. They all involved the creation of an intergovernmental body, such as a multi-ministerial steering committee, chaired by a strong ministry (e.g., Finance) or the Prime Minister's Office. In Tunisia, for instance, the government is implementing a multisector investment project to promote value chain development and job creation. The project is co-managed by the Ministries of Finance, Industry, Labor, and Social Affairs. Similarly, in Bangladesh, the government designed and is implementing a jobs strategy that involves several ministries and sectors.

\subsection{The reality of advanced economies}

Section 3.2 presents a few figures and tables with key trends and issues in formal labor force participation. It also highlights policy trends as well as policy gaps to support high formal labor force participation in advanced countries.

Figure 3.1 presents demographic trends for selected high-income countries (United States, Germany, and Japan) with actual data for the period 2010-2015 and projections thereafter. Actual data signal the falling share of births and rising share of deaths as determinants of population growth, and the growing role of net immigration. The projections keep the share of births broadly constant but gradually increase the share of deaths. The projected fall in net migration is not model-based but a technically and politically convenient assumption by the United Nations that net migration between all countries will eventually become zero (Ayuso, Bravo, and Holzmann 2015a). The rich world is moving to a demographically stagnant or shrinking future, a phenomenon that even record-high rates of net migration will be unable to counteract (Ayuso, Bravo, and Holzmann 2015b). 
Figure 3.1: Contribution of births, deaths, and migration to population growth in highincome countries

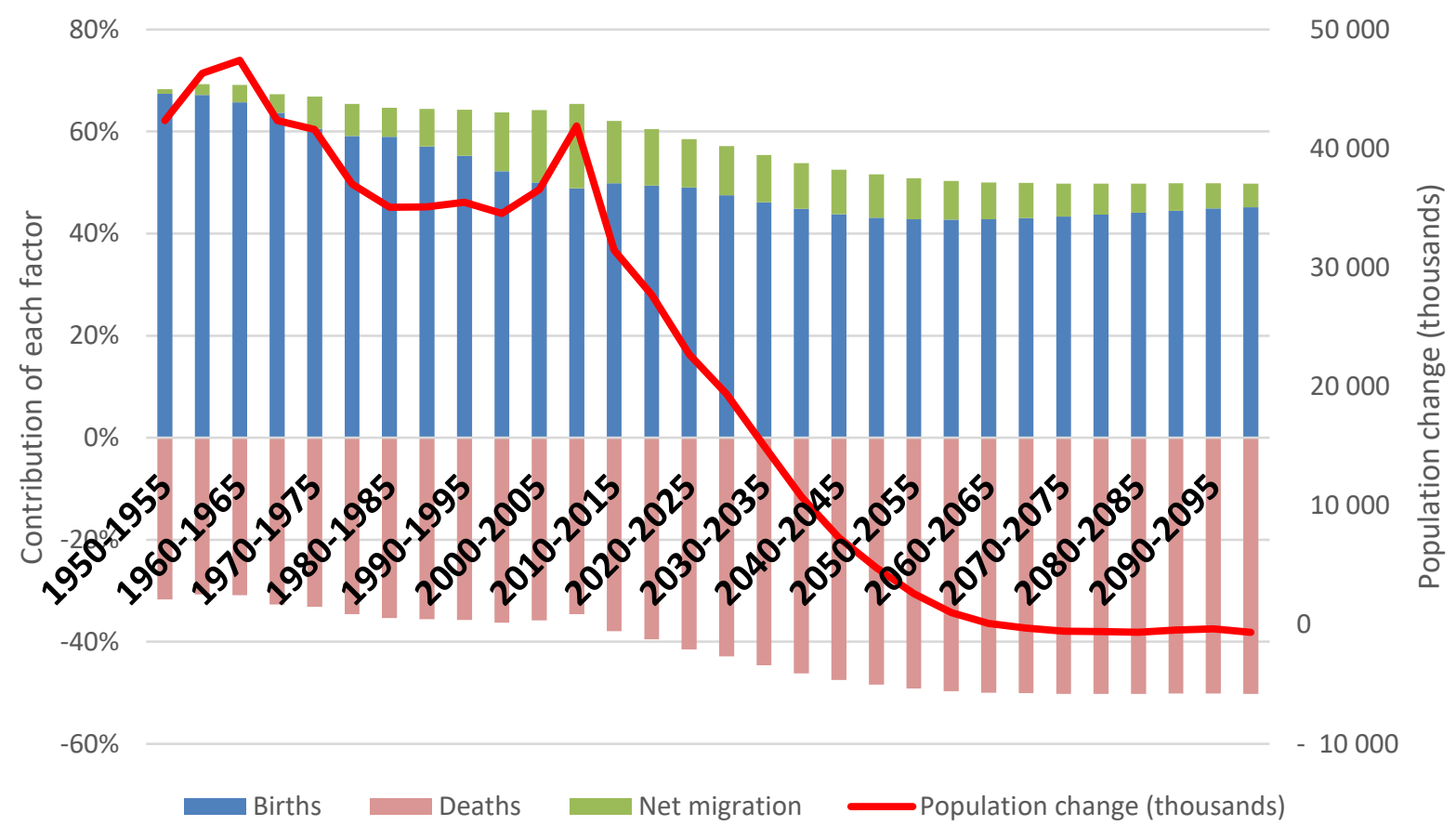

Source: Authors' elaboration based on data from the United Nations, Department of Economic and Social Affairs, Population Division (2017). World Population Prospects: The 2017 Revision, DVD Edition.

Figure 3.2 presents the trends over the last 25 years in labor force participation in highincome countries. The total rate stabilized as the rise in women's participation compensated for the fall in men's. This is in line with the demographic trends. Similarly, the contributor ratio toward the old-age pension scheme in Table 3.1 signals broad stability (across the observed shorter period) with some moderate variations. The differences between countries are noticeable but not sizable and largely expected. Yet in all countries they suggest that the old-age pension coverage or the contribution regularity is incomplete. 
Figure 3.2: Labor force participation, ages $15+$, in high-income countries

Table 3.1: Old-age contributor ratio

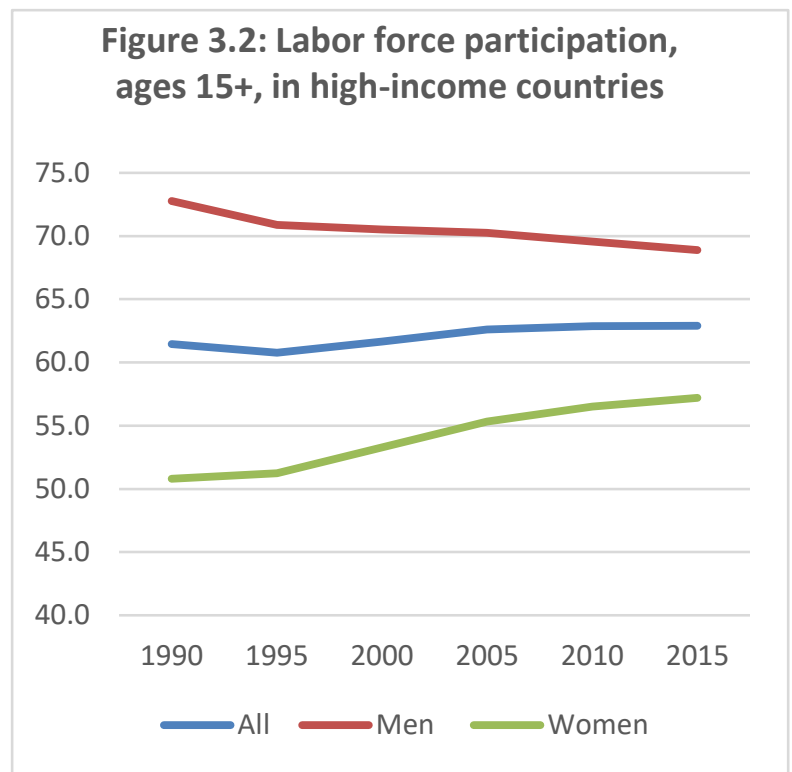

Source: Authors' elaboration based on data from OECD.stat.

Note: Each data point shows the average for fiveyear windows around the corresponding year. For example, data for 1990 are the average for the period 1988-1992.
(\% of working-age population) 2000 to 2014

Australia

Earliest Latest

Israel

$70 \% \quad 70 \%$

Japan

$66 \% \quad 70 \%$

Korea, Republic of

Latvia

$63 \% \quad 71 \%$

Czech Republic $\quad 66 \% \quad 67 \%$

Portugal $\quad 60 \% \quad 59 \%$

Singapore $\quad 46 \% \quad 45 \%$

Slovenia $\quad 60 \% \quad 64 \%$

Source: Data from the ILO Social Security Department. Note: This indicator reflects the extent to which the current working-age population is protected in old age. It is calculated as the number of current contributors to a social security institution providing benefits in old age as a proportion of the working-age population. This version of the old-age demographic protection ratio might slightly understate the future level of protection, as some of those affiliated, but currently not actively contributing to an old age pension scheme, might still build up sufficient entitlements during working age (http://www.ilo.org/dyn/ilossi/ssimain.home?p_lang=en).

Beyond these selective and incomplete graphs and tables, and consistent with the literature, various pension and labor market issues emerge. Three are discussed here. They are selected as they harbor critical policy issues for which the conceptual and empirical guidance is very thin:

- While increasing the number of immigrants can increase the size of the working-age population, it cannot stop the process of demographic aging (Bussolo, Koettl, and Sinnott 2015). Moreover, when it comes to the role of unmanaged immigration for the financing of the pension scheme and other social programs, there are two key 
questions: (i) What is the likelihood of unskilled, and often illegal economic migrants, integrating sufficiently into the labor market of sophisticated economies to pay taxes and contributions, when even low-skilled nationals have difficulty doing so? and (ii) What is the impact on an NDC type scheme of middle-aged yet labor market-fit migrants who are offered an old-age minimum income guarantee (as this combination makes contributions akin to taxes)?

- Formal pension scheme coverage typically increases with countries' income/development level but not necessarily at the same pace. Yet the expectation was once that eventually and with sufficiently high income, essentially all countries would have full pension coverage. This was not the case before the 2008 financial crisis, and indications suggest that coverage may have peaked in Organisation for Economic Co-operation and Development (OECD) countries toward the end of the last century (Holzmann 2003). Since then labor market marginalization has reportedly increased. And the arrival of industry 4.0, robots, and artificial intelligence is expected to further increase the contributory marginalization. What does this mean for future coverage and how can this be best handled by NDC schemes?

- Over the last decades a number of countries moved toward FDC and NDC schemes and most traditional NDB schemes underwent reforms of diverse depth. This calls for empirical analyses of differences in the labor market and scheme participation and their changes over time. Can such differences be established or have they been smoothed over by other scheme characteristics? Or are the differences between DC and reformed DB schemes actually irrelevant? The answers matter significantly for reform design. Encouraging reports on positive NDC labor market effects are seen in the country papers of Latvia, Norway, Poland, and Sweden (Volume 1).

With regard to the policy trends and reform gaps in the pension/labor market area, the following observations are noteworthy: 
- The information base suggests that both NDB and NDC reforms were mostly undertaken for reasons of financial sustainability, with only limited concern for labor market interactions and outcomes. The elimination of the tax wedge through a closer contribution-benefit link seems of concern to economists but less so to policy makers.

- Concerns are increasing about the marginalization and precarious position of a subset of the population and the implications for future pension rights (under NDB and NDC schemes alike), but limited interest or even legislated actions exist to correct the resulting low contribution density during active life; e.g., through matching contributions and other promising mechanisms. Any corrections undertaken typically happen ex post. Is this due to the different effectiveness of interventions, merely reflecting budgetary shortsightedness?

- Over the last two decades, zero pillar arrangements expanded and essentially all high-income countries now have such an instrument. Yet this was done with little concern for distortion-minimizing integration with earnings-related schemes and the impact on labor market outcomes.

\subsection{The reality of emerging economies}

Section 3.3 also presents key trends and issues in formal labor force participation, and highlights policy trends as well as policy gaps to support high formal labor force participation, but this time in emerging economies. The focus is on countries in the Europe and Central Asia (ECA), Latin America and the Caribbean (LAC), and East Asia and Pacific (EAP) regions, or a subset of those countries depending on data availability.

Figure 3.4a-c presents the components of demographic change with the same period of observed data (until 2010-2015) and projected data thereafter. While commonalities driven by slowing fertility rates and reduced mortality rates exist among the regions, differences also arise. In both LAC and EAP the demographic transition is still in full swing; in ECA the transition is long over. The projected negative population change in LAC and EAP starts in 
the second half of this century, but has already occurred in ECA. Both LAC and EAP are net migration contributors, while in ECA net migration went from positive to negative. The negative net migration and negative population growth were stark in a number of ECA countries - for example, Latvia and Bulgaria lost over one-quarter of their population.

Figure 3.5a-c presents the regions' labor force participation trends. As these data are difficult to obtain, the figures for ECA cover only Russia, Poland, Romania, and Turkey, and for EAP only the Philippines and Thailand. Hence the data may not be representative. The data suggest lower labor force participation rates than typically expected in OECD countries in all regions, with the highest rates in EAP (i.e., the Philippines and Thailand). No noticeable trend of increase is observed for men and women combined in any of these regions. The same applies for men alone, with major differences between the regions. Scope differences are lower for women but a rising participation trend for women is observed.

Figure 3.3 compares a measure of benefit coverage across regions, including high-income countries as a benchmark. The figure exhibits the main differences in coverage across the regions of emerging countries, although their per capita income is broadly similar. ECA has the highest coverage rate, which came down from very high rates during the early years of economic transition with a small increase thereafter. LAC follows with a lower rate but a noticeable increase during the most recent 15 years. The lowest rate but also the highest change is observed for EAP. Overall, a major coverage gap exists in all emerging country regions. This presents a major challenge for all existing pension schemes and would also challenge even a perfectly designed and implemented NDC scheme. 
Figure 3.3: Old-age contributor ratio, 2000-2014

(in \% of working-age population; nearest years)

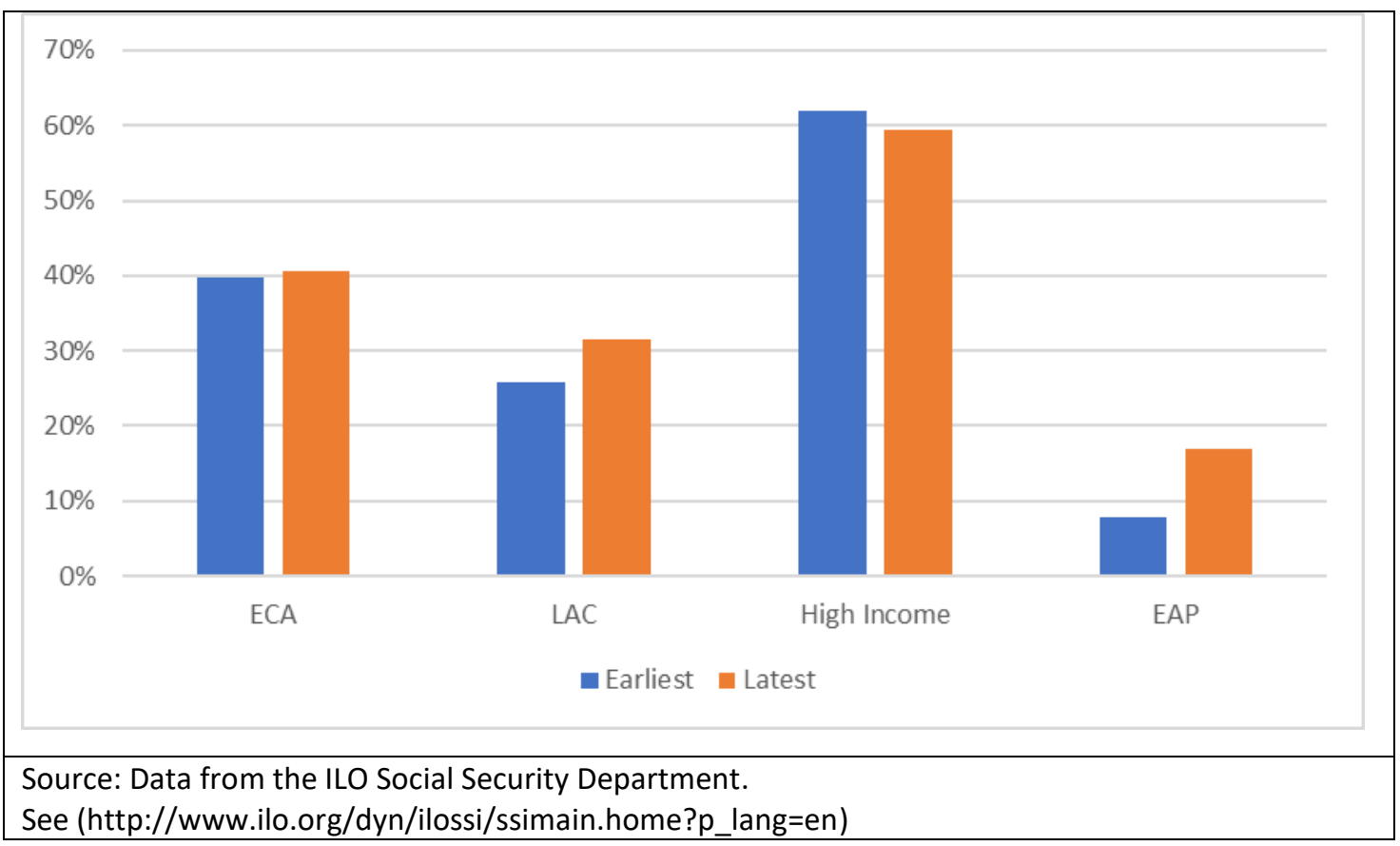


Figure 3.4a, b, and c: Contribution of births, deaths, and migration to population development in LAC, EAP, and ECA

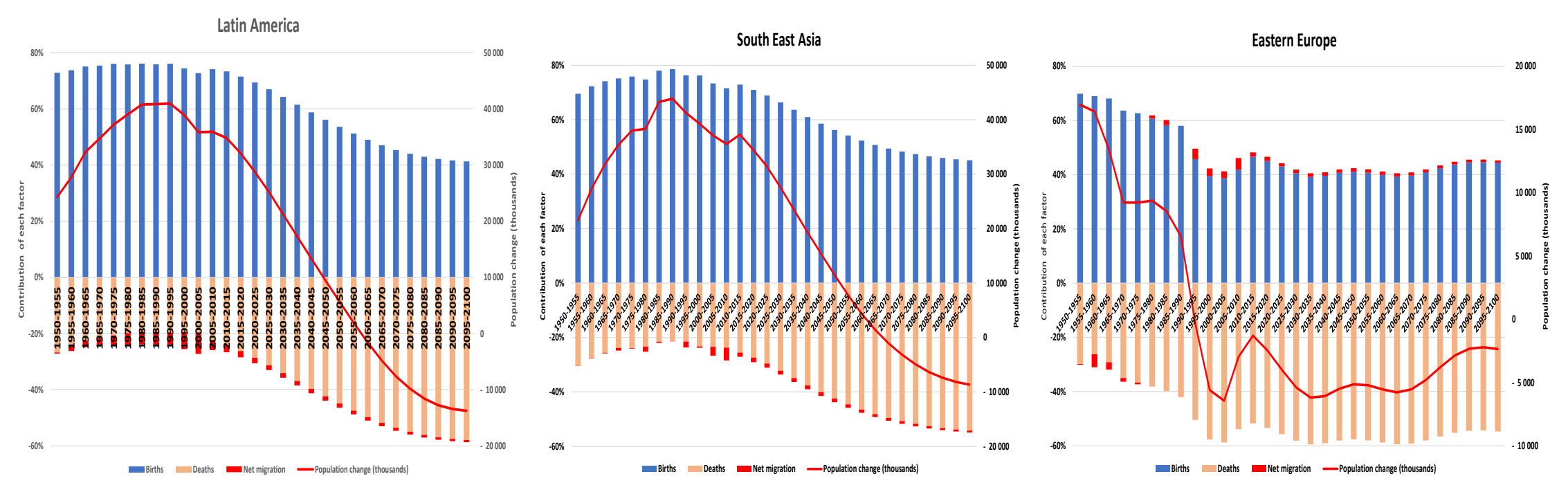

Source: Authors' elaboration based on data from the United Nations 2017).

Figure 3.5a, b, and c: Labor force participation rates (age 15+) by gender in ECA, LAC, and EAP

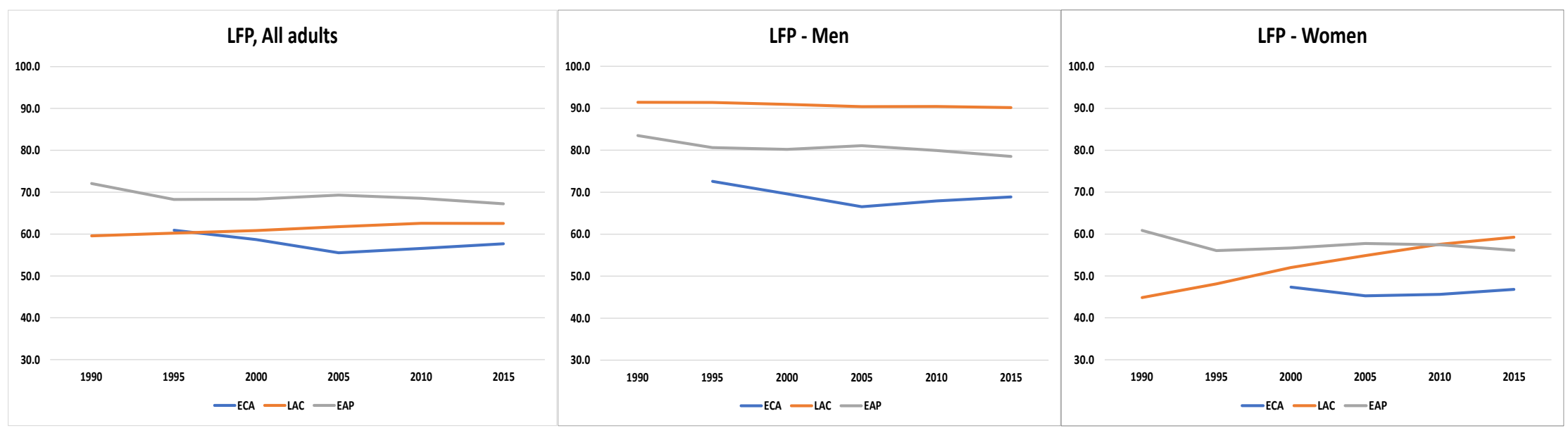

Source: Authors' elaboration based on data from ILOSTAT (for LAC and EAP) and OECD.stat (for ECA). 
Beyond these figures and based on a rich literature on the topic, many issues emerge, including:

- The strong emigration from a number of ECA countries puts a major stress on their pension system, as contributors in best working age are leaving the country. Some may return during their active age (such as Poles leaving the United Kingdom); others may move to other European countries; and some may return after retirement. While this offers little problem for individuals and their portability of acquired rights/benefits disbursement, it creates challenges for the cash flows of these countries' pension schemes and for the calculation of the sustainable (notional) rate of return when an NDC scheme is involved and the cross-country flow of workers is sizable. However, the experience of Latvia, which lost almost one-third of its labor force in the past two decades, strongly suggests that the NDC approach is well able to master a shrinking workforce (Palmer and Stabina 2019).

- Old-age coverage increased but still has room to grow before reaching that of highincome countries (which themselves are dealing with a decrease). In addition the relevant studies observe a continued low contribution density for lower- and at times higher-income groups in these countries. Under a pure DC scheme this would result in very low benefit levels in retirement. Currently benefit gaps are handled with ex post top-ups on low benefits once received, and with the introduction of zero pillars in many emerging economies. This is laudable but risks aggravating the coverage problem as the tax wedge between the formal and informal sectors is increased (Levy 2008; Pages, Rigolini, and Robalino 2014).

With regard to the policy trends and reform gaps on the pension/labor market, the following comments are made:

- Many pension policy reforms were undertaken or attempted in the 1990s and 2000s in LAC, ECA, and Central (Mongolia, Kyrgyz Republic, Kazakhstan) and East Asia (Korea, China) to address short- and long-term financial sustainability through 
introduction of funded DC pillars that were partially reversed thereafter. The reversal was often fiscal in view of the sizable transition costs. As in high-income countries, coverage and labor market issues played a very limited role in the reform process of emerging economies.

- Informality remains a problem in emerging economies of LAC and EAP, and became an issue in ECA with the transition. The discussion in LAC reflects the view that expanded basic provisions plus high costs of formality create a tax wedge that makes informality a rational choice (Levy 2008). In Asia, the mandated but unfunded character of public provisions is claimed to be an obstacle to formalization. The preference for funded provisions mixed with reservations about social security institutions remains high there.

- Pension policy is mostly developed with little regard for and understanding of labor market issues. Pension staff in social security institutions and related ministries typically have little information about the labor market connection and issues. The relevant policy makers hardly talk to each other and those technically in charge of pension reform have a limited understanding of labor market challenges and limited guidance on how to handle them.

\section{NDC schemes and delayed retirement}

Many of the labor market inadequacies and distortions during early and middle working life carry over into the labor market for older workers. In addition, specific labor market issues exist for the elderly that are likely to impact their retirement decisions. Section 4.1 offers key NDC design and labor market policy issues and options for delaying retirement in line with increasing life expectancy and broader population aging. Many circumstances risk undoing the promised neutrality of NDC schemes with regard to retirement decisions. The next two subsections present trends in labor force participation of the elderly and effective retirement ages, and explore the extent to which the design and policy issues are reflected 
in policy discussions and interventions in advanced (section 4.2) and emerging (section 4.3) economies.

\subsection{Key NDC design suggestions and main labor market policy actions/options}

The close contribution-benefit link of an NDC scheme promises not only a low or no tax wedge for labor supply decisions. It also promises to create a linear intertemporal budget constraint for an individual so that retirement depends only on his/her preferences for consumption and leisure and the shadow price of leisure (i.e., the wage rate). In consequence and in principle, it is not necessary to set any retirement age, benefit receipt can be mixed with continued labor market participation in any combination, and the delay in retirement in line with the increased life expectancy should be smooth and welfareoptimizing.

\subsubsection{Key NDC design issues for retirement delay}

The concept of an individual linear intertemporal budget constraint established by an NDC scheme is presented in Figure 4.1. The budget constraint measures lifetime labor supply when moving from $E$ - the entry point to the labor market - to the left on the leisure axis $L$. The angle is the wage rate, or the opportunity cost of leisure. The realized labor earnings buy one a consumption bundle $\mathrm{C}$. Depending on his/her preferences for leisure and consumption, an individual chooses a point on the linear intertemporal budget constraint (solid line), and thus retirement age $\mathrm{R}$.

Figure 4.1a presents a situation where the standard retirement age $R_{s}$ happens to be the welfare optimal choice $A$ on the intertemporal budget constraint. The choice $A$, however, may also emerge under a somewhat different preference set if after the standard retirement age the intertemporal budget constraint has a kink, due to, for example, a lower wage rate from this age onward.

Figure $4.1 \mathrm{~b}$ presents an individual with a much lower wage rate who has access at minimum retirement age to guaranteed income that lifts his/her intertemporal budget constraint to 
point $B$ and keeps it constant thereafter (as the wage rate for further labor supply is assumed zero). This shift in his/her intertemporal budget constraint is the result of a redistributive process during the retirement years. As a result, most preference sets will make $B$ an individually optimal selection. If the individual has a very low life expectancy that moves the consumption axis toward the minimum retirement age, then withdrawal from the labor market before the minimum retirement age may be optimal (and the mandated contributions act as a mere tax).

Figure 4.1: Intertemporal budget constraint and selection of the retirement age

a. High-income earner

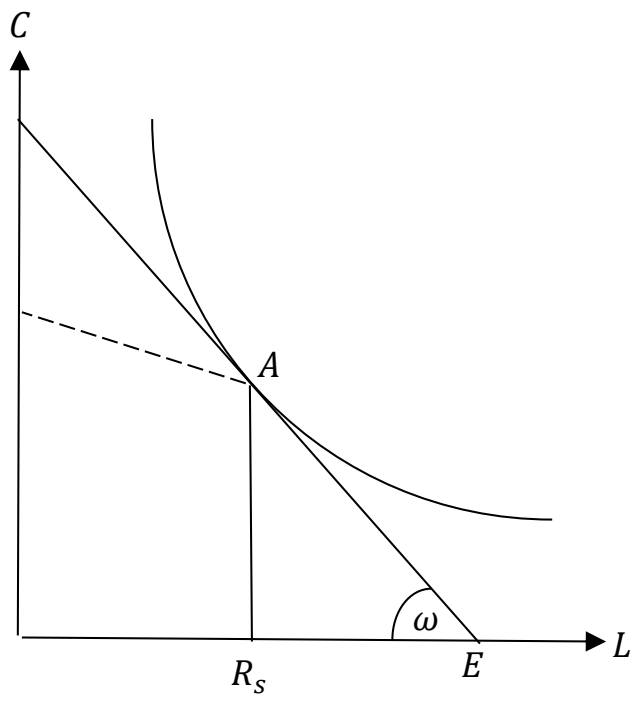

b. Low-income earner with guaranteed minimum at minimum retirement age

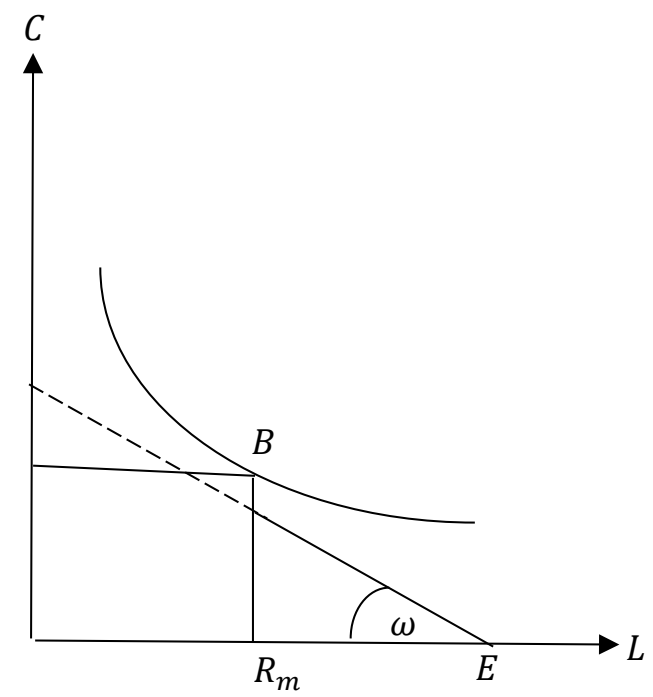

The following briefly illustrates some of the considerations that may undo the linearity of NDC schemes and instead establish kinks around the minimum or standard retirement age:

- The tax treatment of earnings and pensions matters. With high social security contributions and high marginal tax rates on active income, net (consumption) income before and after retirement may not be too different and thus labor supply may fall to zero as soon as the minimum benefit access age is reached. 
- Access to occupational pensions is typically contingent on withdrawal from a firm's labor market. Lacking alternative job opportunities in other firms or being offered lower wage rates makes full withdrawal at the first possible moment attractive.

- A number of family events can shift preferences and encourage earlier retirement, including a spouse's withdrawal from the labor market (and the increase in joint leisure utility) or the need or opportunity to care for grandchildren (e.g., due to absent child care institutions - a frequently cited early retirement argument in Italy).

- Interactions with other social programs such as access to or loss of survivors', disability, or health care benefits at a specific age may affect early retirement - e.g., substituting government-subsidized health care for self-financed private provisions is one such scenario.

- For lower-income groups, minimum income guarantees or top-ups from a certain age onward may lead not only to a kink but to a jump in the intertemporal budget constraint, making this retirement age a rational choice (as in Figure 4.1b).

- For individuals with lower life expectancy, the left axis moves to the right, making earlier retirement preferences rational and the choice of the earliest possible moment optimal. Such a preference is strengthened by a frontloading of NDC benefits, which offer higher initial benefits for lower indexation thereafter (as very transparently done under the Swedish NDC scheme).

These and other circumstances that undo the linearity of the individual intertemporal budget constraint and risk bringing the retirement decision forward suggest that the design of minimum or standard access rules, the redesign of other social programs, and the availability of rewarding job opportunities are ever more critical as life expectancy increases and people are expected to postpone retirement. The following are only some of many possible benefit redesign considerations:

- In view of the importance of the minimum access age to (NDC) benefits for retirement decisions, its indexation with some measure of remaining life expectancy seems required. 
- Retirement/take-up of benefits may not be granted at minimum access age to individuals with insufficient own accumulations; the rules may ask for accumulations/annuity equivalents of at least a guaranteed minimum income level. In this case a higher (and life expectancy-indexed) access age to a guaranteed minimum income needs to be selected; this can be a notional standard retirement age or a higher selected access age.

- Low-income individuals are likely to have a lower life expectancy; this needs to be taken into consideration when deciding on the first two design proposals.

- While the standard retirement age loses, in principle, any meaning under an NDC approach, selection of a notional standard retirement age and its indexation to the related cohort life expectancy may be crucial as a signaling/nudging device.

\subsubsection{Key labor market policy challenges and options}

The key policy challenge is to make society understand that population aging is: (i) a very new development for mankind - it started only about 250 years ago in advanced countries; (ii) expected to continue without end in sight; and (iii) likely the most important socioeconomic change since the beginning of mankind - at least as significant as climate change and its consequences (Holzmann 2013). As a result, the concomitant increase in retirement age will stay and must be proactively addressed. This calls for an appropriately structured system of retirement programs as well as innovative, far-reaching, and wellimplemented labor market policies.

To outline the full scope of required policy changes in the labor market and other key policy areas is well beyond the scope of this paper (see Börsch-Supan 2003; Holzmann 2013; Piggott and Woodland 2016). A few pertinent policy considerations and options around the labor market are offered here:

- The right regulatory framework of an economy is quite likely crucial to keep individuals healthy, skilled, and motivated but knowledge regarding how to design the regulations is lacking. What can be done to incentivize individuals to follow a 
healthy lifestyle throughout their lives? This is important for extended labor force participation but also to address the health costs of an aging society and to make longer life more enjoyable. To this end, the empirical knowledge of effective programs is very limited as is the political willingness to implement them (except, perhaps, by some European green parties). Similar knowledge gaps apply to the relevant skills enhancements for an older work force. Lifelong learning is popular in political speeches but the conceptual and empirical foundation for effective programs remains weak as rigorous monitoring and evaluation is essentially absent (OECD 2005; European Commission/EACEA/Eurydice 2015). Empirical research has found some strategies to keep older workers motivated (such as changing one's job and work environment, including colleagues), but employers must have the right incentives to offer the elderly jobs.

- For employers to have incentives to offer jobs to older workers, suggestions include:

- Revise the strict protection rules for the older workforce seen in most countries that can be counterproductive for new hires;

- Review the seniority principle of wage setting, which periodically incrementally raises wages for workers simply because they are getting older; instead move to a productivity-oriented wage-setting process that keeps older workers competitive; and

- Offer more contract flexibility with an elderly workforce to overcome asymmetric skills. This may explain why employers in OECD countries have problems maintaining existing older workers in their workforce beyond retirement age, but are highly reluctant to hire unfamiliar older workers.

- Whatever progress can be made at shifting the age-skill profile upward, the mix of skills is changing with age and needs to be accommodated by work assignments to the profit of all. Known approaches include:

- Redefining the role of the elderly. Firms in advanced countries in this area (such as Finland and Germany) have started to change the work process for 
elderly workers on the production line or to move them into mentor positions for younger workers, with reportedly measurable success ${ }^{7}$; and

- Accommodating a preretirement job change, e.g., through reassignment within the unit or changing to a new employer/self-employment. For employees in enterprises and administration, retirement at the highest job level will need to be a feature of the past.

\subsection{The reality of high-income economies}

Section 4.2 highlights trends and issues in retirement age, and policy trends as well as policy gaps to support increasing retirement age in high-income countries.

Figure 4.2 presents the trend in labor force participation of individuals age $65+$ for select high-income countries for the last 25 years. A clear change can be seen from the decadeslong trend of ever-decreasing labor force participation of the elderly for both genders. This trend is mirrored in the decreased effective average retirement age from a larger dataset of rich OECD countries since 1970 (Figure 4.3). The retirement age came down from levels of over 68 years for men to as low as 63 years in 1996 and 1997 before rising after the 2008 financial crisis to 64.5 years in 2014. The same happened for women, for whom the retirement age is one year lower.

\footnotetext{
7 See Ilmarinen (2005) for an early review of issues and Finnish approaches, and read the success story on "BMW 2017" and changes made to the production line to support an aging labor force (Bauer and Mauermann 2010).
} 
Figure 4.2: Labor force participation-aged

$65+$ in high-income countries (United

States, Germany, Japan), 1990-2015

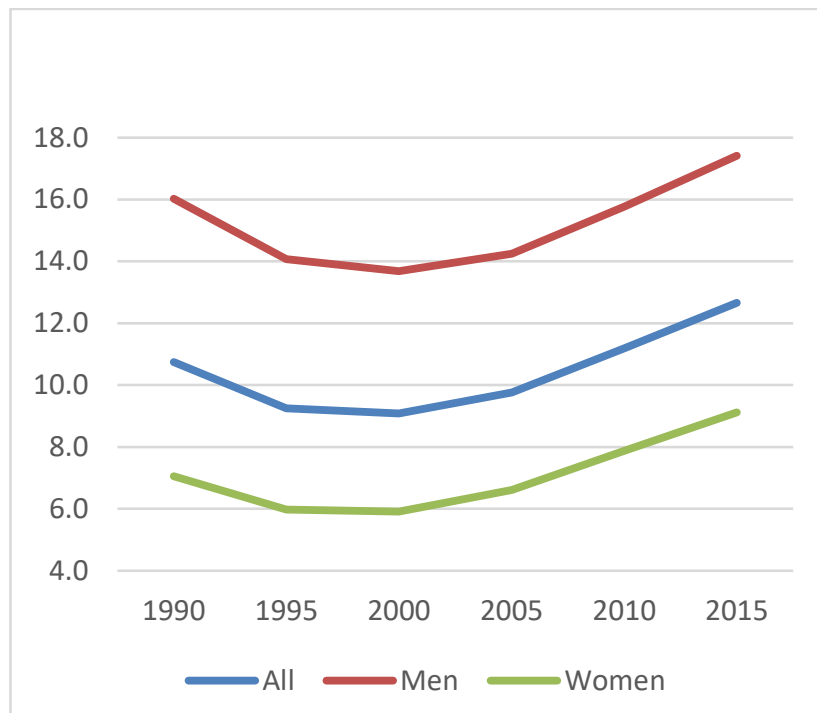

Figure 4.3: Effective average retirement age in high-income OECD countries, 1970-2014

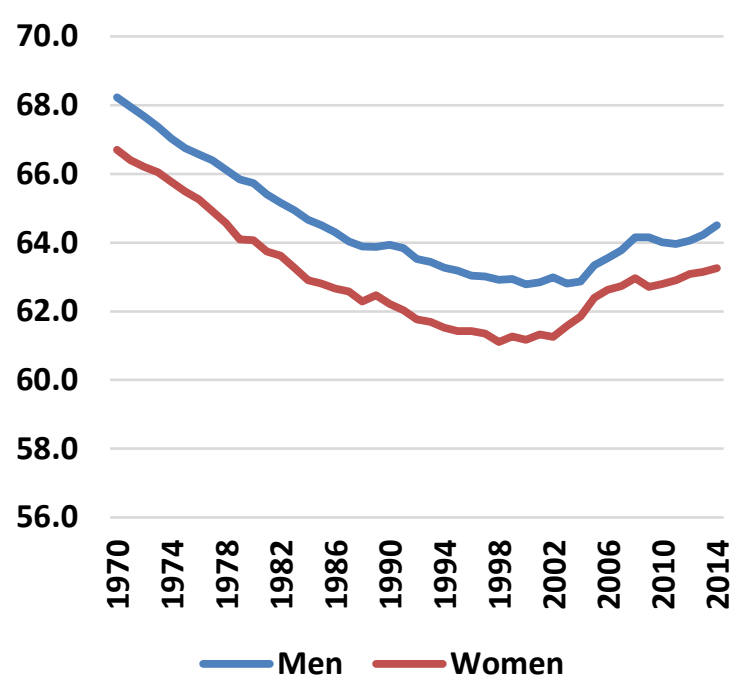

Source: Authors' elaboration based on data from OECD.stat.

This development is likely the result of increases in the legal retirement age and the introduction of decrements (increments) for earlier (later) retirement; it may also be influenced by the reduction in public generosity as well as periodic stock market disturbances; and it may be codetermined by the retirement of baby boomers, which often left skill gaps that employers were willing to cover by keeping elderly workers employed longer. ${ }^{8}$

Despite this positive trend, some remaining issues include:

- In most but not all advanced economies an increase in the labor force participation of the elderly and in effective retirement ages took place. This explains the moderate change seen since the end 90 s, which reflects the average of both leaders and laggards. Hence a number of other advanced countries still have to act to reverse current trends.

\footnotetext{
${ }^{8}$ For a first analysis of the German development of elderly men's and women's labor force participation, see Börsch-Supan and Ferrari (2017).
} 
- For those countries that substantially increased their effective retirement age, two related but distinct questions emerge:

- Was the increase sizable enough to compensate for the intermediate increase in life expectancy at this age? For the three front-running countries with increases of 3.3 to 4.2 years between 1996 and 2014, this was quite likely the case. Life expectancy at birth increases by about 2.5 years per decade, and at retirement by about 1.5 years. Thus, the current effort of the large majority of high-income countries was insufficient if only to catch up with recent increases in life expectancy.

- Did the trend in effective retirement lead to financially sustainable schemes? Given the answer above, this does not seem the case (even assuming adjustments in the benefit level and more). This calls for further legal action for the retirement age, benefit reforms, or introduction of a NDC scheme.

- Similar to the increase in labor force participation raised above, the empirical issue stands whether NDC or FDC schemes have been more successful at increasing the effective retirement age than reformed or unreformed NDB schemes. The available data do not allow this question to be answered.

With regard to the policy trends and reform gaps for the retirement age and labor market participation of the elderly in advanced economies, the following observations are suggested:

- Essentially all OECD countries have started to increase the retirement age of men and women, but often with long implementation periods (OECD 2017). Some countries have started to index the standard retirement age to changes in life expectancy. In most countries this approach will not be sufficient to establish financial sustainability because the starting age is too low, the effort too timid, and/or no commitment to reducing the accrual rate is undertaken.

- Most countries use an estimate of period life expectancy and its expected changes to anchor their retirement policy instead of the methodologically correct estimate of 
the cohort life expectancy. There is strong empirical evidence from countries that produce and publish both estimates that the period life expectancy at retirement underestimates the cohort life expectancy by 30 percent and more (Ayuso, Bravo, and Holzmann 2018).

- There is only limited public recognition that population aging is here to stay, that a continuous increase in the legal and effective retirement age is the first-best option to address it, and that the mandated pension scheme and overall pension system need to be made population aging-compliant.

- With regard to the elderly on the labor market, significant differences arise between country approaches, from a purely market-driven one (as in the United States - you take the job that you get) to a government/social partner-driven one (as in Finland).

- There is no understanding of the need for a comprehensive reform approach that addresses each of the potential binding constraints for delayed retirement - from the redesign of the disability pension and minimum income guarantee to labor market reforms that offer capabilities and opportunities for elderly workers.

- No advanced economies have a systematic approach to keep the elderly healthy, skilled, and motivated, and to increase the incentives (decrease disincentives) of employers to offer jobs to elderly workers. And no international inventory exists with which to compare and rigorously assess the applied approaches.

\subsection{The reality of emerging economies}

Figure 4.4 presents the labor force participation rate of individuals aged $65+$ for the regions (and countries) presented in section 3.3. Three observations stand out:

- In all three regions the labor force participation rate at age 65+ is broadly constant or falling. The latter is the case for ECA, whose rate is now lower than the OECD average. 
- For all three regions the starting value in 1990 was well above that of high-income countries. In LAC and EAP the rate still remains well above the rate of these countries.

- In LAC the rate remains broadly high for men, but there is a slight increase in the rate from much lower levels for women.

Figure 4.5 presents complementary information on the effective retirement age for a subset of countries in LAC and ECA and in China. The results are broadly but not fully consistent and not easily explained except by different country examples:

- For LAC (covering Brazil, Chile, and Mexico) the retirement age for both genders is falling from very high levels, with fluctuations across the period from the early 1970 s to 2014.

- The information for China suggests an essentially constant effective retirement age for men of about 66 years. For women the data suggest an increase in waves.

- The data for ECA countries (Bulgaria, Croatia, Latvia, Lithuania, Poland, Romania, and Turkey) show an OECD-type profile, with a fall and a subsequent rise after the end of the 1990s. The increases since its lowest value are higher than the average for high-income OECD countries. The recent increase in effective retirement age was able to compensate for the rise in life expectancy (Gal and Rado 2019).

The analytical issues raised are the same as those for high-income OECD countries, in particular the questions of: (i) whether the re-increase in ECA countries was sufficient to compensate for the progress in life expectancy; and (ii) whether the increase was linked to the type of pension reform introduced.

With regard to the policy trends and reform gaps for the retirement age and labor market participation of the elderly in advanced economies, the following observations are suggested:

- Emerging economies have seen only a slow policy drive to increase the legal retirement age: in some it is under discussion, in a very few it has been legislated. 
While experts strongly recommend an increase in the retirement age among countries in EAP, only Korea, Japan, and Singapore have made progress in this area (World Bank 2016). In ECA, many countries (e.g., Bulgaria, the Czech Republic, Estonia, Hungary, Latvia, Poland, Romania, Slovenia, and Turkey) are gradually increasing the retirement age, as well as restricting eligibility or lowering benefit levels for early retirement (Bussolo, Koettl, and Sinnott 2015).

- Emerging economies seem to have even less of an understanding than advanced economies that population aging is here to stay, and that the overall pension system thus needs to be made population aging-compliant.

- Proposals in these countries for increasing the legal and effective retirement age are typically rejected by the "lump of labor fallacy" position and views that the current elderly (compared to those in advanced economies) are less fit and less skilled to work longer.

- Emerging economies may have even higher heterogeneity in longevity than advanced economies. This creates an even starker challenge for the redesign of benefit schemes and minimum pension age and guarantees.

- Emerging economies seem to have no understanding of and hence no comprehensive/systematic approach for policies to keep the elderly healthy, skilled, and motivated, and to increase the incentives (decrease the disincentives) of employers to offer jobs to elderly workers. 
Figure 4.4a, b, and c: Labor force participation-aged 65+ in LAC, EAP, and ECA by gender, 1990-2015

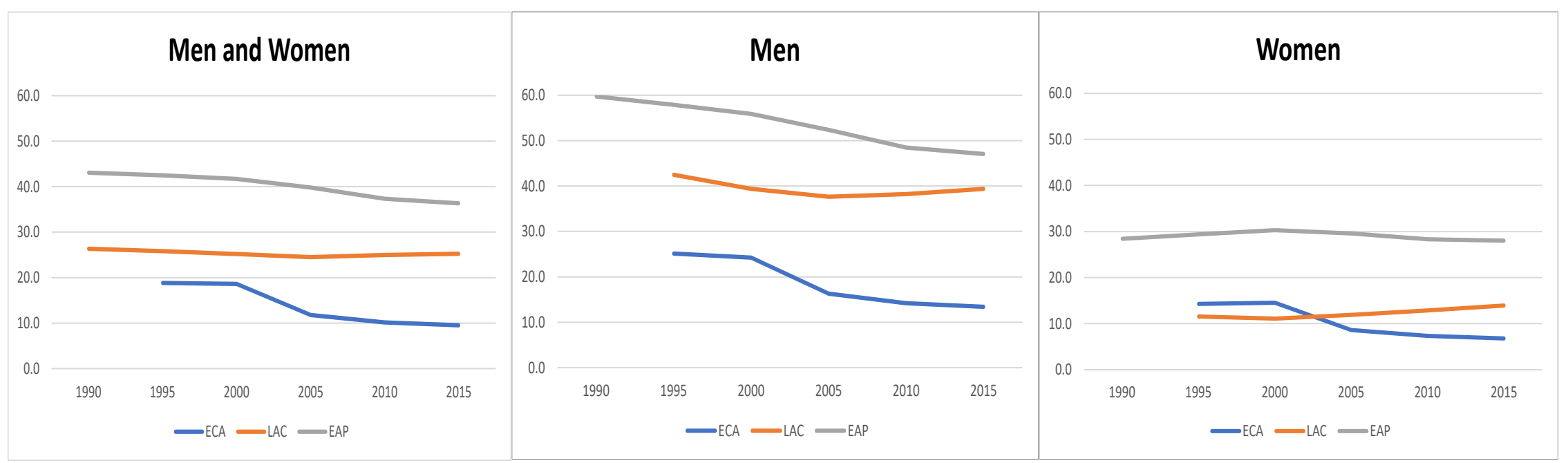

Source: Authors' elaboration based on data from ILOSTAT (for LAC and EAP) and OECD.stat (for ECA).

Figure 4.5a, b, and c: Effective average retirement age in LAC, China, and ECA by gender, 1970-2014

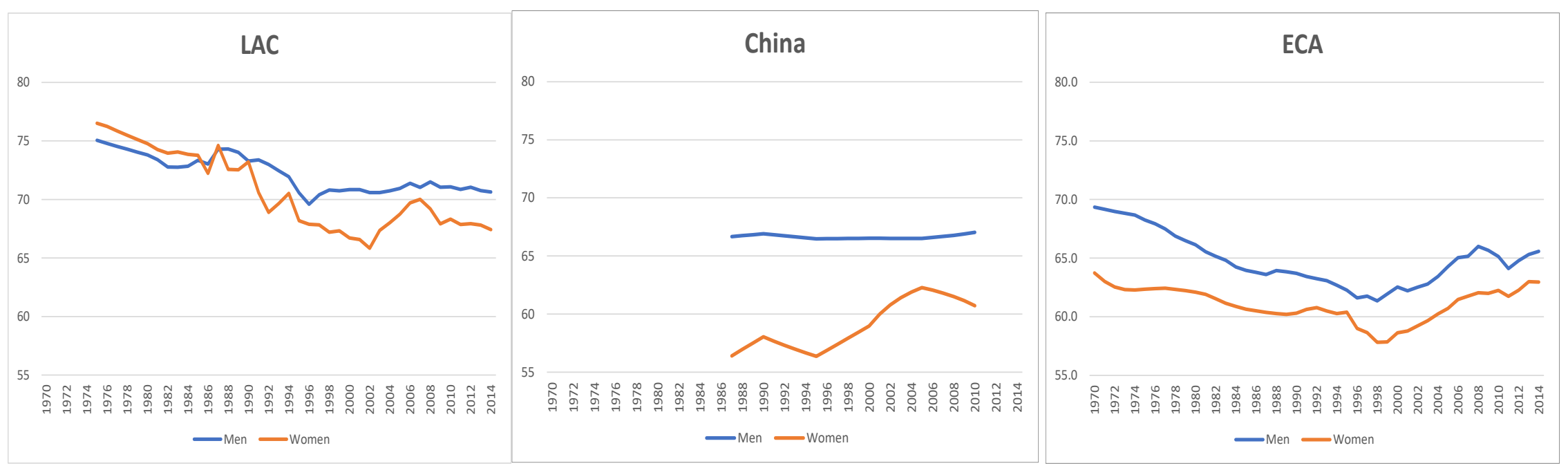

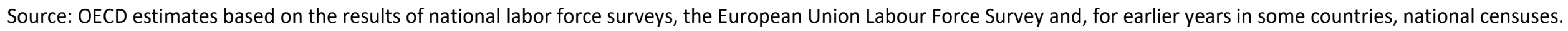

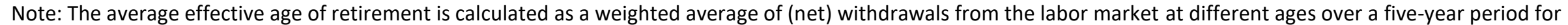

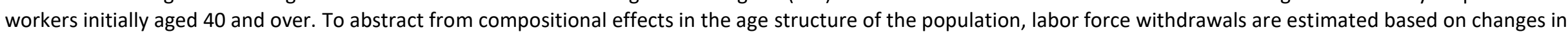
labor force participation rates rather than labor force levels. These changes are calculated for each (synthetic) cohort divided into five-year age groups. 


\section{Conclusions and next steps}

This paper analyzes the constraints that NDC schemes face to live up to their promise of creating strong incentives for formal labor force participation and high contribution density, and for delaying retirement in line with rising life expectancy. These constraints include design and implementation issues, behavioral shortcomings that affect retirement and savings decisions, and structural problems in labor markets that affect the share of wage employment and/or work opportunities during old age. Despite these constraints, (F\&N) DC schemes remain the most promising earnings-related pension system to address not only population aging but also the impact of new technologies (robots and artificial intelligence) on labor markets.

This paper discusses (re-) design features and labor market policies needed for NDC schemes to fully deliver the expected labor market outcomes. Labor policies, in particular, are likely to differ between advanced and emerging economies, taking into consideration structural differences in labor market conditions.

Low formal labor force participation and contribution density remain an issue in emerging economies but marginalization and fragmentation in the labor market has reemerged as an issue in advanced economies. This creates a huge challenge for benefit design and social and labor policies to find the right balance between assistance and work incentives. Or it calls for a completely new thinking around the individual account design.

In a world of continual population aging, the extension of working life is considered the most adequate response, and NDC schemes offer the most promising instrument for achieving this. Yet public recognition of these two issues is limited in advanced economies and essentially nonexistent in emerging economies. Benefit design issues remain largely unresolved, and the required policies associated with the labor market for the elderly are, for the most part, terra incognita.

These challenges are not unique to NDC schemes. They apply equally to FDC schemes as the main mandated or supplementary pillar. But the argument still holds that both NDC and 
FDC schemes can address the demographic and labor market challenges better than any (N\&F) DB scheme, however well reformed. What is missing is an integrated approach to design DC schemes, social/family policies, and labor market policies to improve the performance of pension systems and achieve better labor market outcomes. 


\section{References}

Akbaş, Merve, Dan Ariely, David A. Robalino, and Michael Weber. 2016. "How to Help the Poor to Save a Bit: Evidence from a Field Experiment in Kenya." IZA Discussion Papers No. 10024, Bonn, Germany.

Almeida, Rita, and Pedro Carneiro. 2012. "Enforcement of Labor Regulation and Informality." American Economic Journal: Applied Economics 4(3): 64-89.

Ayuso, Mercedes, Jorge Bravo, and Robert Holzmann. 2015a. "Revisión de las Proyecciones de Población: Más Allá de los Convenientes Supuestos Sobre Fertilidad, Mortalidad y Migración." Instituto BBVA de Pensiones, Documento de Trabajo № 11/2015. Madrid: BBVA.

. 2015b. “Revisión de las Proyecciones de Población, Parte 3: Respuestas de la Política Demográfica al Envejecimiento de la Población: Familia, Mercado Laboral y Migración." Instituto BBVA de Pensiones, Documento de Trabajo № 14/2015. Madrid: BBVA.

. 2017a. "On the Heterogeneity in Longevity among Socioeconomic Groups: Scope, Trends, and Implications for Earnings-Related Pension Schemes." Global Journal of Human Social Sciences-Economics 17(1): 33-58.

. 2017b. "Addressing Longevity Heterogeneity in Pension Scheme Design." Journal of Finance and Economics 6(1): 1-24.

. 2018. "Getting Life Expectancy Estimates Right for Pension Policy: Period versus Cohort Approach." Paper prepared for the BBVA Expert Forum, Madrid.

Banerji, Arup, Robert Holzmann, Pierella Paci, Carmen Pages, Stefano Scarpetta, and Milan Vodopivec. 2008. “Miles to Go: A Quest for an Operational Labor Market Paradigm for Developing Countries." World Bank, Washington, DC.

Bauer, Nikolaus, and Helmut Mauermann. 2010. "How BMW is Defusing the Demographic Time Bomb." Harvard Business Review March: 99-102. 
Bertrand, Marianne, Senhil Mullainathan, and Douglas Miller. 2003. "Public Policy and Extended Families: Evidence from Pensions in South Africa." World Bank Economic Review 17(1): 27-50.

Bodor, Andras, and Robert Holzmann. 2016. “GCC Labor Markets: Challenges and Policy Options." Gulf Affairs 2015, Labor Market Dynamics in the GCC States 1: 30-31.

Börsch-Supan, Axel. 2003. "Labor Market Effects of Population Aging." Labour, Special Issue 17: $5-44$.

Börsch-Supan, Axel, and Irene Ferrari. 2017. “Old-age Labor Force Participation in Germany: What Explains the Reversal Among Older Men? And What About the Steady Increase Among Older Women?" NBER Working Paper Series, WP 24044, NBER, Cambridge, MA.

Bussolo, Maurizio, Johannes Koettl, and Emily Sinnott. 2015. Golden Aging: Prospects for Healthy, Active, and Prosperous Aging in Europe and Central Asia. Washington, DC: World Bank.

Davidoff, Thomas, Jeffrey R. Brown, and Peter A. Diamond. 2005. "Annuities and Individual Welfare." American Economic Review 95(5): 1573-1590.

Delarue, Antoine. 2013. “Using Prepaid Contributions to Cover Mobile Workers in Cape Verde and Tunesia." In Matching Contributions for Pensions, ed. Richard Hinz, Robert Holzmann, David Tuesta, and Noriyuki Takayama, Chapter 13, pp. 261-274. Washington, D.C.: World Bank.

European Commission/EACEA/Eurydice. 2015. Adult Education and Training in Europe:

Widening Access to Learning Opportunities. Eurydice Report. Luxembourg: Publications Office of the European Union.

Finezylber, Eduardo. 2017. “Chile's Solidarity Pillar: A Benchmark for Adjoining Zero Pillar with DC Schemes." Social Protection and Jobs Discussion Paper, No. 1910. Washington, D.C.: World Bank Group. 
Frölich, Markus, David Kaplan, Carmen Pagés, Jamele Rigolini, and David Robalino, eds. 2014. Social Insurance, Informality, and Labour Markets: How to Protect Workers While Creating Good Jobs. No. 7879. Oxford, UK: Oxford University Press.

Gal, Robert, and Marta Rado. 2019. "Labor Market Participation and Postponed Retirement in Central and Eastern Europe." Social Protection and Jobs Discussion Paper, No. 1915. Washington, D.C.: World Bank Group.

Gentilini, Hugo, Philip Okeef, Truman Packard, Robert Palacios, David Robalino, and Indhira Santos. Forthcoming. "Social Protection and Jobs in a Changing World of Labor." Jobs Group, Working Paper. World Bank, Washington, DC.

Gruber, Jonathan, and David Wise. 1998. "Social Security and Retirement: An International Comparison." The American Economic Review 88(2), Papers and Proceedings of the Hundred and Tenth Annual Meeting of the American Economic Association: 158-163.

Hampf, Franziska, and Ludger Woessmann. 2017. "Vocational vs. General Education and Employment over the Life Cycle: New Evidence from PIAAC." CESifo Economic Studies 63(3): 255-269.

Hausmann, Ricardo, Danny Rodrik, and Andres Velasco. 2005. Growth Diagnostics. Cambridge, MA: John F. Kennedy School of Government, Harvard University.

Hofer, Helmut, and Reinhard Koman. 2006. "Social Security and Retirement in Austria." Empirica 33(5): 285-313.

Holzmann, Robert. 2003. "A Provocative Note on Coverage in Public Pension Schemes." In The Three Pillars of Wisdom - A Reader on Globalization, World Bank Pension Models and Welfare Society, ed. Anton Tausch, pp. 85-99. New York: Nova Science Publisher.

. 2013. "An Optimistic Perspective on Population Aging and Old-Age Financial Protection." Malaysian Journal of Economic Studies 50(2): 107-137. 
. 2014. "Participation in Mandated and Voluntary Social Risk Management

Arrangements: The Role and Limits of Financial Education and Other Interventions". In Social Insurance and Labor Markets: How to Protect Workers While Creating Good Jobs, ed. Fröhlich, Markus, David Kaplan, Carmen Pagés, Jamele Rigolini, and David Robalino, pp. 147-179. Oxford University Press for Inter-American Development Bank and World Bank.

. 2017a. "Do Bilateral Social Security Agreements Deliver on the Portability of Pensions and Health Care Benefits? A Summary Policy Paper on Four Migration Corridors Between EU and Non-EU Member States." IZA Journal of European Labor Studies 5(17): 1-35.

. 2017b. "The ABCs of NDCs." International Social Security Review 70(3): 53-77.

. 2019. "The ABCs of NDCs." Social Protection and Jobs Discussion Paper, No. 1908.

Washington, D.C.: World Bank Group.

Holzmann, Robert, and Richard Hinz. 2005. Old-Age Income Support in the 21st Century: An International Perspective on Pension Systems and Reform. Washington, DC: The World Bank.

Holzmann, Robert, and Alain Jouston. 2013. "Addressing the Legacy Costs in an NDC Reform: Conceptualization, Measurement, and Financing." In NDC Pension Schemes in a Changing Pension World, Volume 2: Gender, Politics, and Financial Stability, ed. Robert Holzmann, Edward Palmer, and David Robalino, Chapter 18, pp. 277-304. Washington, DC: World Bank.

Holzmann, Robert, and Johannes Koettl. 2015. "The Portability of Pensions, Health, and Other Social Benefits: Concepts and Issues." CESifo Economic Studies 61(2): 377-415.

Holzmann, Robert, and Edward Palmer. 2012. "NDC in the Teens: Lessons and Issues." In NDC Pension Schemes in a Changing Pension World, Volume 1: Progress, Issues, and Implementation, ed. Robert Holzmann, Edward Palmer, and David Robalino, Chapter 1, pp. 1-29. Washington, DC: The World Bank and Swedish Social Insurance Agency. 
Holzmann, Robert, Landis Mackellar, and Jana Repansek, eds. 2009. Pension Reform in SouthEastern Europe: Linking Pension Reform with Labor and Financial Market Reforms. Washington, DC: The World Bank and Ljubljana: Center for Financial Excellence.

Holzmann, Robert, Jennifer Alonso-García, Heloise Labit-Hardy, and Andrés M. Villegas. 2017. "NDC Schemes and Heterogeneity in Longevity: Proposals for Redesign." IZA Discussion Papers No. 11193, December. Bonn, Germany.

. 2019. "NDC Schemes and Heterogeneity in Longevity: Proposals for Redesign." Social Protection and Jobs Discussion Paper, No. 1913. Washington, D.C.: World Bank Group.

Ilmarinen, Juhani. 2005. Toward a Longer Working Life. Ageing and the Quality of Worklife in the European Union. Helsinki: Finish Institute of Occupational Health.

Kotlikoff, Laurence J., and Avia Spivak. 1981. "The Family as an Incomplete Annuities Market." Journal of Political Economy 89 (2): 372-391.

Kruse, Agneta, and Ann-Charlotte Ståhlberg. 2017. “Rethinking Disability Insurance, Survivors' Insurance and Old Age Care Under NDC Reform." Revised paper presented at the 3rd NDC Conference, Rome, October 5-6, 2017; January.

Levy, Santiago. 2008. Good Intentions, Bad Outcomes. Washington, DC: Brookings Institution.

Merotto, Dino, Michael Weber, and Reyes Aterido. 2017. "Jobs Diagnostics Facts and Findings." Jobs Group Working Paper, World Bank, Washington, DC.

Nelson, Kenneth, Rense Nieuwenhuis, and Susanne Alm. 2019. "Sweden: Adjoining the Guarantee Pension with NDC." Social Protection and Jobs Discussion Paper, No. 1909. Washington, D.C.: World Bank Group.

Organisation for Economic Co-operation and Development (OECD). 2005. Promoting Adult Learning. Paris: OECD Publishing. 

2017. Pension at a Glance. Paris: OECD Publishing.

Pages, Carmen, Jamele Rigolini, and David Robalino. 2014. "Social Insurance, Informality and Labor Markets: How to Protect Workers While Creating Good Jobs." In Social Insurance, Informality and the Labor Markets, ed. Markus Frölich, David Kaplan, Carmen Pagés, Jamele Rigolini, and David Robalino, pp. 8-27. Oxford: Oxford University Press.

Palacios, Robert. 2019. "Administrative Requirements and Prospects for Universal NDCs in Emerging Economies." Social Protection and Jobs Discussion Paper, No. 1920. Washington, D.C.: World Bank Group.

Palmer, Edward, and Sandra Stabina. 2019. "The Latvian NDC Scheme: Success Under a Decreasing Labor Force." Social Protection and Jobs Discussion Paper, No. 1902. Washington, D.C.: World Bank Group.

Piggott, John, and Alain Woodland. 2016. Handbook of the Economics of Population Aging, Volume 1A. Amsterdam: North Holland.

Ribe, Helena, David Robalino, and lan Walker. 2012. From Right to Reality: Incentives, Labor Markets, and the Challenge of Universal Social Protection in Latin America and the Caribbean. Washington, D.C.: World Bank.

Robalino, David, and lan Walker. 2017. "Economic Analysis of Jobs Investment Projects." Guidance Note, Jobs Group Working Paper No. 7, World Bank, Washington, DC.

Robalino, David, Ian Walker, et al. Forthcoming. "Maximizing the Employment Effects of Matching Grants for SMEs." Jobs Group Working Paper, World Bank, Washington, DC.

Tommasi, Mariona, and Andres Velasco. 2007. "Where Are We in the Political Economy of Reform?" The Journal of Policy Reform 1(2): 187-238.

World Bank. 2012. World Bank Development Report 2013: Jobs. Washington, D.C.: World Bank. 
. 2016. Live Long and Prosper: Aging in East Asia and Pacific. Washington, DC: World Bank. 


\section{Social Protection \& Jobs Discussion Paper Series Titles 2017-2019}

No. $\quad \underline{\text { Title }}$

1929 Developing Coherent Pension Systems: Design Issues for Private Pension Supplements to NDC Schemes by William Price

April 2019

Pensions in a Globalizing World: How Do (N)DC and (N)DB Schemes Fare and Compare on Portability and Taxation?

by Bernd Genser and Robert Holzmann

April 2019

1927 The Politics of NDC Pension Scheme Diffusion: Constraints and Drivers

by Igor Guardiancich, R. Kent Weaver, Gustavo Demarco, and Mark C. Dorfman

April 2019

1926 Setting Up a Communication Package for the Italian NDC

by Tito Boeri, Maria Cozzolino, and Edoardo Di Porto

April 2019

1925 Sweden's Fifteen Years of Communication Efforts

by María del Carmen Boado-Penas, Ole Settergren, Erland Ekheden, and Poontavika Naka

April 2019

1924 Information and Financial Literacy for Socially Sustainable NDC Pension Schemes

by Elsa Fornero, Noemi Oggero, and Riccardo Puglisi

April 2019

1923 Communicating NEST Pensions for "New" DC Savers in the United Kingdom

by Will Sandbrook and Ranila Ravi-Burslem

April 2019

Harnessing a Young Nation's Demographic Dividends through a Universal NDC Pension Scheme: A Case

Study of Tanzania

by Bo Larsson, Vincent Leyaro, and Edward Palmer

April 2019

1921 The Notional and the Real in China's Pension Reforms

by Bei Lu, John Piggott, and Bingwen Zheng

April 2019

1920 Administrative Requirements and Prospects for Universal NDCs in Emerging Economies

by Robert Palacios

April 2019

1919

Bridging Partner Lifecycle Earnings and Pension Gaps by Sharing NDC Accounts

by Anna Klerby, Bo Larsson, and Edward Palmer

April 2019 
by Agnieszka Chłoń-Domińczak, Marek Góra, Irena E. Kotowska, Iga Magda, Anna Ruzik-Sierdzińska, and Paweł Strzelecki

April 2019

1917 Drivers of the Gender Gap in Pensions: Evidence from EU-SILC and the OECD Pension Model by Maciej Lis and Boele Bonthuis

April 2019

1916 Gender and Family: Conceptual Overview

by Nicholas Barr

April 2019

1915 Labor Market Participation and Postponed Retirement in Central and Eastern Europe by Robert I. Gal and Márta Radó

April 2019

$1914 \quad$ NDC Schemes and the Labor Market: Issues and Options by Robert Holzmann, David Robalino, and Hernan Winkler April 2019

1913 NDC Schemes and Heterogeneity in Longevity: Proposals for Redesign by Robert Holzmann, Jennifer Alonso-García, Heloise Labit-Hardy, and Andrés M. Villegas April 2019

1912 Annuities in (N)DC Pension Schemes: Design, Heterogeneity, and Estimation Issues by Edward Palmer and Yuwei Zhao de Gosson de Varennes April 2019

1911 Overview on Heterogeneity in Longevity and Pension Schemes by Ron Lee and Miguel Sanchez-Romero

April 2019

1910 Chile's Solidarity Pillar: A Benchmark for Adjoining Zero Pillar with DC Schemes by Eduardo Fajnzylber

April 2019

1909 Sweden: Adjoining the Guarantee Pension with NDC by Kenneth Nelson, Rense Nieuwenhuis, and Susanne Alm April 2019

1908 The ABCs of NDCs by Robert Holzmann April 2019

1907 NDC: The Generic Old-Age Pension Scheme by Marek Góra and Edward Palmer April 2019

1906 The Greek Pension Reforms: Crises and NDC Attempts Awaiting Completion by Milton Nektarios and Platon Tinios April 2019 
1904 The Polish NDC Scheme: Success in the Face of Adversity by Sonia Buchholtz, Agnieszka Chłoń-Domińczak, and Marek Góra April 2019

1903 The Italian NDC Scheme: Evolution and Remaining Potholes by Sandro Gronchi, Sergio Nisticò, and Mirko Bevilacqua April 2019

The Latvian NDC Scheme: Success Under a Decreasing Labor Force by Edward Palmer and Sandra Stabina April 2019

The Swedish NDC Scheme: Success on Track with Room for Reflection by Edward Palmer and Bo Könberg April 2019

Rapid Social Registry Assessment: Malawi's Unified Beneficiary Registry (UBR) by Kathy Lindert, Colin Andrews, Chipo Msowoya, Boban Varghese Paul, Elijah Chirwa, and Anita Mittal, November 2018 by Ugo Gentilini, Sarah Laughton and Clare O’Brien, November 2018 by Afrah Alawi Al-Ahmadi and Samantha de Silva, July 2018

1705 Aging and Long-Term Care Systems: A Review of Finance and Governance Arrangements in Europe, North America and Asia-Pacific

by Laurie Joshua, November 2017

1704 Social Registries for Social Assistance and Beyond: A Guidance Note \& Assessment Tool by Phillippe Leite, Tina George, Changqing Sun, Theresa Jones and Kathy Lindert, July 1027

Social Citizenship for Older Persons? Measuring the Social Quality of Social Pensions in the Global South and Explaining Their Spread by Tobias Böger and Lutz Leisering, July 2017

The Impacts of Cash Transfers on Women's Empowerment: Learning from Pakistan's BISP Program by Kate Ambler and Alan de Brauw, February 2017

Social Protection and Humanitarian Assistance Nexus for Disaster Response: Lessons Learnt from Fiji's Tropical Cyclone Winston by Aisha Mansur, Jesse Doyle, and Oleksiy Ivaschenko, February 2017

To view Social Protection \& Jobs Discussion Papers published prior to 2017, please visit www.worldbank.org/sp. 


\section{ABSTRACT}

Defined contribution $(D C)$ schemes - whether unfunded or funded - are often considered superior to defined benefit (DB) schemes in their ability to address labor market issues, particular in encouraging formal employment and delayed retirement. Conceptually, the assessment is based on superior incentives to work and save. Yet economic and social realities are more complex. This paper explores design and labor market conditions that potentially constrain DC schemes. The paper concludes that to achieve their conceptual potential, DC schemes require design innovations, including a better integration of basic provisions and complementary labor policies that promote job creation in the formal sector and expand job opportunities during old age.

\section{ABOUT THIS SERIES}

Social Protection \& Jobs Discussion Papers are published to communicate the results of The World Bank's work to the development community with the least possible delay. This paper therefore has not been prepared in accordance with the procedures appropriate for formally edited texts.

For more information, please contact the Social Protection Advisory Service, the World Bank, 1818 H Street, N.W., Room G7-803, Washington, DC 20433, USA. Telephone: +1 (202) 458 5267, Fax: +1 (202) 614 0471, E-mail: socialprotection@worldbank.org or visit us on-line at www.worldbank.org/sp. 